\title{
In vitro simulation of oxic/suboxic diagenesis in an estuarine fluid mud subjected to redox oscillations
}

\author{
Gwenaël Abril $^{\mathrm{a}, \mathrm{b}, *}$, Marc-Vincent Commarieu ${ }^{\mathrm{a}, \mathrm{c}}$, Henri Etcheber ${ }^{\mathrm{a}}$, Jonathan Deborde ${ }^{\mathrm{a}, \mathrm{d}}$, \\ Bruno Deflandre ${ }^{a}$, Milos K. Živađinović ${ }^{a, c}$, Gwenaëlle Chaillou ${ }^{a, e}$, Pierre Anschutz ${ }^{a}$ \\ a Laboratoire Environnements et Paléoenvironnements OCéanique (EPOC), Université Bordeaux 1, CNRS-UMR 5805, Avenue des Facultés, F 33405 Talence, France \\ ${ }^{\mathrm{b}}$ Institut de Recherches pour le Développement (IRD), Universidad do Estado do Amazonas (UEA), Centro de Estudos Superiores do Trópico Úmido, Manaus, Amazonas, Brazil \\ ${ }^{\mathrm{c}}$ Université de Liège, Unité d'Océanographie Chimique, Institut de Physique (B5), B-4000 Liège, Belgium \\ ${ }^{\mathrm{d}}$ Institut de Recherches pour le Développement (IRD), Centre de Nouméa, BPA5, 98848 Nouméa, Nouvelle Calédonie, France \\ e Département de Biologie, Chimie et Géographie, Université du Québec à Rimouski, 300 Allée des Ursulines, G5L 3A1 Rimouski (QC) Canada
}

\section{A R T I C L E I N F O}

\section{Article history:}

Received 20 February 2009

Accepted 6 April 2010

Available online 14 April 2010

\section{Keywords:}

OM mineralisation

redox oscillations

estuarine turbidity maximum

\begin{abstract}
A B S T R A C T
Estuarine turbidity maxima (ETMs) are sites of intense mineralisation of land-derived particulate organic matter (OM), which occurs under oxic/suboxic oscillating conditions owing to repetitive sedimentation and resuspension cycles at tidal and neap-spring time scales. To investigate the biogeochemical processes involved in OM mineralisation in ETMs, an experimental set up was developed to simulate in vitro oxic/anoxic oscillations in turbid waters and to follow the short timescale changes in oxygen, carbon, nitrogen, and manganese concentration and speciation. We present here the results of a 27-day experiment (three oxic periods and two anoxic periods) with an estuarine fluid mud from the Gironde estuary. Time courses of chemical species throughout the experiment evidenced the occurrence of four distinct characteristic periods with very different properties. Steady oxic conditions were characterised by oxygen consumption rates between 10 and $40 \mu \mathrm{mol} \mathrm{L}^{-1} \mathrm{~h}^{-1}$, dissolved inorganic carbon (DIC) production of 9-12 $\mu \mathrm{mol} \mathrm{L}^{-1} \mathrm{~h}^{-1}$, very low $\mathrm{NH}_{4}^{+}$and $\mathrm{Mn}^{2+}$ concentrations, and constant $\mathrm{NO}_{3}^{-}$production rates $\left(0.4-0.7 \mu \mathrm{mol} \mathrm{L}^{-1} \mathrm{~h}^{-1}\right)$ due to coupled ammonification and nitrification. The beginning of anoxic periods ( $24 \mathrm{~h}$ following oxic to anoxic switches) showed DIC production rates of $2.5-8.6 \mu \mathrm{mol} \mathrm{L}^{-1} \mathrm{~h}^{-1}$ and very fast $\mathrm{NO}_{3}^{-}$consumption $\left(5.6-6.3 \mu \mathrm{mol} \mathrm{L}^{-1} \mathrm{~h}^{-1}\right)$ and $\mathrm{NH}_{4}^{+}$production $\left(1.4-1.5 \mu \mathrm{mol} \mathrm{L}^{-1} \mathrm{~h}^{-1}\right)$. The latter rates were positively correlated to $\mathrm{NO}_{3}^{-}$concentration and were apparently caused by the predominance of denitrification and dissimilatory nitrate reduction to ammonia. Steady anoxic periods were characterised by constant and low $\mathrm{NO}_{3}^{-}$concentrations and DIC and $\mathrm{NH}_{4}^{+}$productions of less than 1.3 and $0.1 \mu \mathrm{mol} \mathrm{L}^{-1} \mathrm{~h}^{-1}$, respectively. $\mathrm{Mn}^{2+}$ and $\mathrm{CH}_{4}$ were produced at constant rates (respectively 0.3 and $0.015 \mu \mathrm{mol} \mathrm{L}^{-1} \mathrm{~h}^{-1}$ ) throughout the whole anoxic periods and in the presence of nitrate. Finally, reoxidation periods (24-36 h following anoxic to oxic switches) showed rapid $\mathrm{NH}_{4}^{+}$and $\mathrm{Mn}^{2+}$ decreases to zero (1.6 and $0.8-2 \mu \mathrm{mol} \mathrm{L}^{-1} \mathrm{~h}^{-1}$, respectively) and very fast $\mathrm{NO}_{3}^{-}$production $\left(3 \mu \mathrm{mol} \mathrm{L}^{-1} \mathrm{~h}^{-1}\right)$. This $\mathrm{NO}_{3}{ }^{-}$production, together with marked transient peaks of dissolved organic carbon a few hours after anoxic to oxic switches, suggested that particulate OM mineralisation was enhanced during these transient reoxidation periods. An analysis based on $\mathrm{C}$ and $\mathrm{N}$ mass balance suggested that redox oscillation on short time scales (day to week) enhanced OM mineralisation relative to both steady oxic and steady anoxic conditions, making ETMs efficient biogeochemical reactors for the mineralisation of refractory terrestrial $\mathrm{OM}$ at the land-sea interface.
\end{abstract}

(c) 2010 Elsevier Ltd. All rights reserved.

\footnotetext{
* Corresponding author. Laboratoire Environnements et Paléoenvironnements OCéanique (EPOC), Université Bordeaux 1, CNRS-UMR 5805, Avenue des Facultés, F 33405 Talence, France.

E-mail address: g.abril@epoc.u-bordeaux1.fr (G. Abril).
}

\section{Introduction}

Mineralisation of terrestrially derived particulate organic matter $(\mathrm{OM})$ is one of the major processes that drive ecosystem metabolism at the land-sea interface and makes near-shore coastal systems net heterotrophic environments and $\mathrm{CO}_{2}$ sources for the atmosphere (Frankignoulle et al., 1998; Gattuso et al., 1998; Borges, 
2005). A net loss of OM from riverine particles has been reported in many estuarine and deltaic environments, in spite of the relatively refractory nature of this terrestrial material in comparison with marine-born particulate OM (Keil et al., 1996; Abril et al., 2002; Blair et al., 2004; Etcheber et al., 2007). Land-derived particles often accumulate in particular coastal zones, like estuarine turbidity maxima (ETM) or deltaic mobile muds (DMMs) on the near-shore continental shelf, where they stay for months or years before being transferred back to coastal lagoons and wetland sediments or to the shelf break and deep seafloor (Jouanneau et al., 1999, 2008; Allison et al., 2000). These shallow estuarine and coastal environments are characterised by frequent resuspension of superficial sediments and the formation of transient benthic turbid structures called "fluid mud", induced by changes in hydrodynamics. In ETMs, sedimentation and resuspension cycles are controlled by tidal currents and occur predominantly on semidiurnal and neap-spring time scales (Abril et al., 1999). In DMMs, storms and waves are the major drivers of resuspension, which generally occur on time scales of several months (Aller, 1998; Allison et al., 2000). As a consequence, land-derived particles experience continuous redox oscillations, spending some time settled in anoxic sediments and some time suspended in the oxic water column. The loss of relatively refractory POM from terrestrial origin that occurs in ETMs and DMMs suggests a link between redox oscillation and POM mineralisation efficiency (Aller, 1998; Abril et al., 2002; Blair et al., 2004; Aller and Blair, 2006; Middelburg and Herman, 2007).

The impact of redox oscillations induced by sediment resuspension on the mineralisation of terrestrial particulate OM is still only partially understood. Aller $(1994,1998)$ discussed that redox changes could enhance particulate OM mineralisation through two major groups of biogeochemical processes. First, mixing of terrestrial OM with much more labile marine or estuarine OM occurs frequently and promotes co-oxidation. Labile OM in muds includes living phytoplankton cells and detritus, bacterial biomass that is recycled after each redox change and transient fermentative compounds that become very labile in oxic conditions (Sun et al., 1993; Aller, 1994). Second, reduced inorganic compounds and nutrients are frequently recycled and become available again for diagenetic reactions and heterotrophic activities. The study of the vertical distribution of redox species in estuarine and deltaic fluid muds (Aller, 1998; Abril et al., 1999, 2000; Aller et al., 2004) has revealed that suboxic conditions dominate. This is probably because reduced nitrogen, manganese and iron are periodically reoxidised, forming nitrate and poorly crystallised oxides on the suspended particles, which are then available to oxidise OM during the next deposition phase (Aller, 1998; Aller et al., 2004). Consequently, sulphate reduction, the classical dominant heterotrophic process in marine sediments (Jørgensen, 1982), becomes minor in comparison with aerobic respiration, denitrification, and $\mathrm{Mn}$ and Fe reduction (Aller, 1998; Abril et al., 1999). In DMMs, where particles reside more than $90 \%$ of their time in anoxic conditions, and where reoxidation frequency is generally more than one month, iron oxides are the major electron acceptor (Aller, 1998; Aller et al., 2004; Aller and Blair, 2006). In contrast, in ETMs where particles spend $50 \%$ of their time in oxic conditions, and where the resuspension frequency is less than a week, vertical profiles in the fluid mud suggest that oxygen, nitrate and Mn oxides dominate as oxidants for OM degradation (Abril et al., 1999, 2000).

Although in situ studies give important information on the nature and time scales of processes occurring in fluid muds, in vitro approaches are necessary to quantify the rates of OM degradation and to investigate how redox oscillations could enhance OM mineralisation. Previous in vitro experiments designed to compare the fate of radio labelled OM or molecular organic tracers under stable or oscillating conditions have provided evidence for much contrasted behaviours of organic compounds under oxic and anoxic conditions. In these studies, a generally faster OM degradation in oxic than in anoxic conditions was found, with oscillations having contrasting effects depending on the nature of the OM (Sun et al., 1993, 2002; Kristensen et al., 1995; Andersen, 1996). Hulthe et al. (1998) showed that the production of dissolved inorganic carbon was similar in oxic and anoxic conditions for labile material, but that for refractory material oxic rates were up to 3.6 times faster than anoxic rates. To our knowledge, no work has attempted to follow and quantify the rates of individual diagenetic reactions and their changes on very short time scales during transient periods of redox oscillation. In the present paper, we present the results of an in vitro study of OM degradation during simulated redox oscillation at time scales representative of those in ETMs. For this study, a special incubator was designed to follow the evolutions of the partial pressures of $\mathrm{CO}_{2}, \mathrm{~N}_{2} \mathrm{O}$ and $\mathrm{CH}_{4}$, the $\mathrm{pH}$, and the concentrations of $\mathrm{NO}_{3}^{-}, \mathrm{NH}_{4}^{+}, \mathrm{NO}_{2}^{-}, \mathrm{Mn}^{2+}, \mathrm{Fe}^{2+}$, $\mathrm{SO}_{4}^{2-}$ and DOC in oxic and anoxic oscillating conditions to better understand the biogeochemical processes involved in OM mineralisation and their interactions.

\section{Materials and methods}

\subsection{Study site}

The Gironde estuary is turbid almost all year, but experiences the most concentrated ETM in the summer, generally at low to intermediate salinities (Abril et al., 2002). A large majority of the particulate OM in the Gironde ETM is of terrestrial origin and has low reactivity (Etcheber et al., 2007). Fluid mud pools, in which the Total Suspended Solids (TSS) concentration ranges between 50 and $400 \mathrm{~g} \mathrm{~L}^{-1}$, settle at neap tides and can reach $2 \mathrm{~m}$ in thickness (Abril et al., 1999). Available in situ data on the fluid mud of the Gironde estuary show that anoxia occurs when the TSS concentration is in the range of $50-150 \mathrm{~g} \mathrm{~L}^{-1}$, depending on the geographical location (Abril et al., 1999). Concentration profiles of redox species suggest that organic matter mineralisation in the fluid mud is dominated by denitrification and reduction by oxides of manganese. In addition, nitrate is rapidly consumed in the upper layer of the fluid mud (150-250 $\left.\mathrm{g} \mathrm{L}^{-1}\right) . \mathrm{Mn}^{2+}$ appears in the more concentrated inner layer (250-450 $\left.\mathrm{g} \mathrm{L}^{-1}\right)$, and production of alkalinity, ammonium, and potentially labile dissolved organic carbon (DOC) were also observed in the fluid mud (Abril et al., 1999, 2000).

\subsection{Incubation setup}

We used a homemade incubator (Fig. 1), which enabled us to maintain a homogenised fluid mud under oxic or anoxic conditions for a determined period of time. The changes in concentrations of major chemical species were measured either continuously in the liquid or gas phases or at regular intervals by sampling, conditioning, and further analysis. The incubation system consisted of a 14.2 L glass vessel set on a magnetic stirrer and thermostatically controlled with a coiled silicone tube. Three orifices in the vial allowed hermetical connection of Teflon seams to a temperature, a $\mathrm{pH}$, and an oxygen sensor. In addition, a tap connected to a $50 \mathrm{~mL}$ syringe allowed the sampling of aliquots without any contact with the atmosphere. The cap of the vessel was equipped with five apertures; two of them were connected by a closed circuit to a gas analyser, allowing sampling of the gas phase; two others were connected to two $5 \mathrm{~L}$ glass vessels set in parallel, one empty and one containing an oxygen trap (Anaerocult, Merck ${ }^{\circledR}$ ). A peristaltic pump circulated the gas through the fluid mud sample at a flow of 


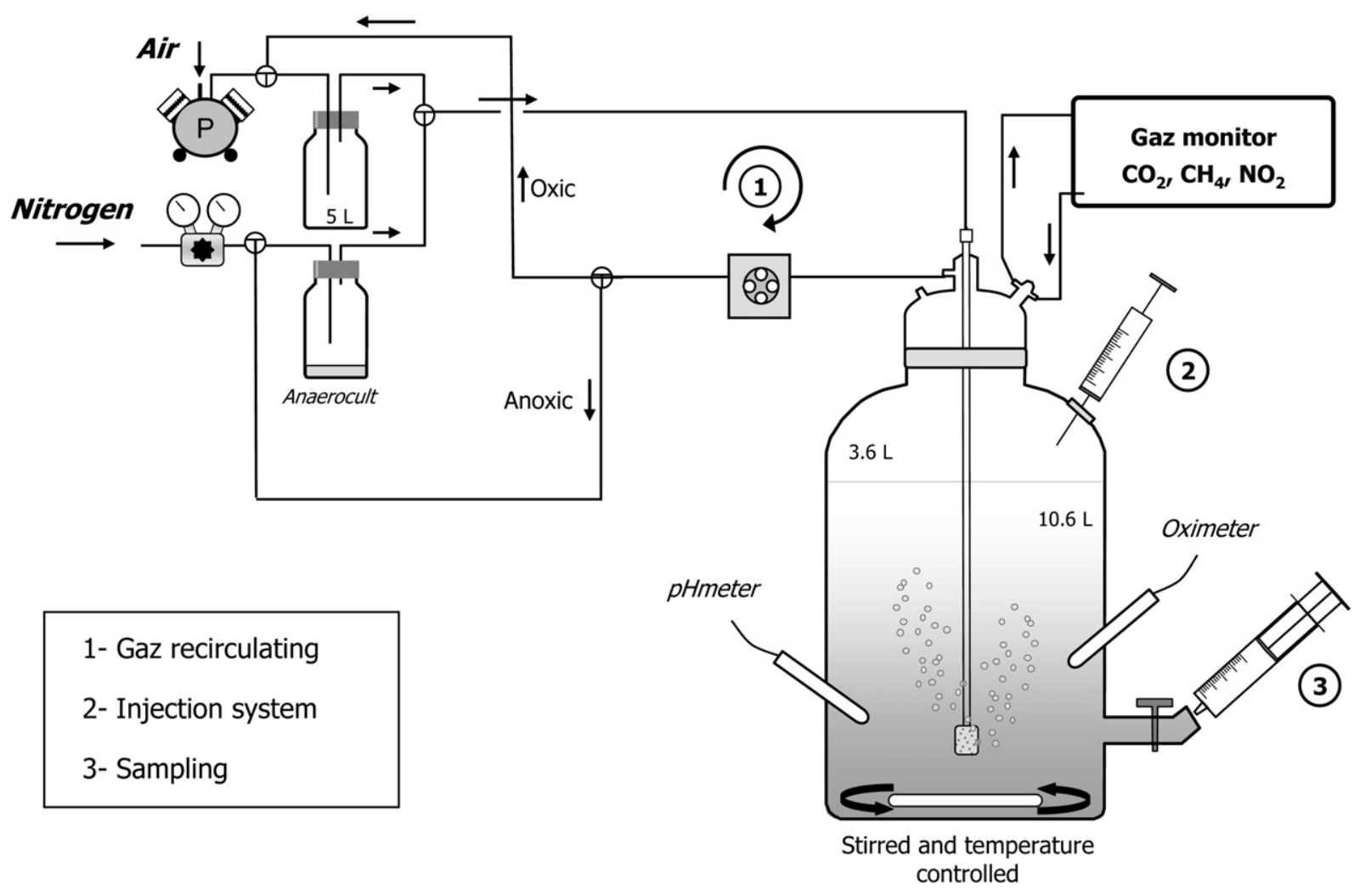

Fig. 1. Experimental set up for incubation of the estuarine fluid mud under oxic or anoxic conditions.

$0.17 \mathrm{~L} \mathrm{~min}^{-1}$ to equilibrate the liquid phase (total volume $10.6 \mathrm{~L}$ ) with the gas phase (total volume $8.6 \mathrm{~L}$ ). The last orifice was fitted with a rubber septum and permitted the injection of reagents with a syringe.

Oxic or anoxic conditions were obtained by occasionally purging the gas and water phases with either air or $\mathrm{N}_{2}$. There was no need to add $\mathrm{CO}_{2}$ to the purging gases to avoid too high of a $\mathrm{pH}$ value for the fluid mud. For anoxic periods, the $\mathrm{N}_{2}$ stream circulated through the vessel containing the oxygen trap to remove traces of $\mathrm{O}_{2}$. About $45 \mathrm{~min}$ was needed for complete conversion from oxic to anoxic conditions, or from anoxic to oxic conditions. When stable conditions were obtained, the system was closed and a peristaltic pump ensured gas circulation. Under oxic conditions, the release of $\mathrm{CO}_{2}$ from respiration strongly decreased the $\mathrm{pH}$. To avoid too low of a $\mathrm{pH}$ value, purges with air were also performed at regular intervals during oxic periods. The selected criterion for these purges was to maintain the $\mathrm{pH}$ above 7.7 , the typical lowest value observed in situ in the fluid mud of the Gironde (Abril et al., 1999).

Continuous measurements in the gas phase were performed with an infrared / photo-acoustic gas analyser (INNOVA 1312), which allowed recording of the partial pressures of carbon dioxide $\left(p \mathrm{CO}_{2}\right)$, methane $\left(p \mathrm{CH}_{4}\right)$ and nitrous oxide $\left(\mathrm{pN}_{2} \mathrm{O}\right)$ every two minutes. In the present study, the gas analyser was calibrated against a Gas Chromatograph-Thermal Conductivity Detector and a Gas Chromatograph-Flame Ionization Detector for analysis on the 0-10,000 ppmv and 0-500 ppmv ranges for $\mathrm{CO}_{2}$ and $\mathrm{CH}_{4}$, respectively $\left(R^{2}>0.98, n=20\right)$. No calibration was performed for $\mathrm{N}_{2} \mathrm{O}$, as this parameter was interpreted qualitatively only. In the liquid phase, $\mathrm{pH}$ and temperature were measured with a Ross combination pH electrode, calibrated every day with NBS buffers, and with a PT100 sensor, respectively. Oxygen was monitored with a polarographic YSI electrode calibrated in water-saturated air.

\subsection{Experimental procedure}

Fifteen litres of fluid mud were sampled with a Niskin bottle in April 2003 during a neap tide period in the Gironde ETM, $50 \mathrm{~cm}$ above the sediment surface. The particulate matter concentration of the sample was $140 \mathrm{~g} \mathrm{~L}^{-1}$, with an organic carbon content of 1.5 dry weight \%, and the salinity was 1.3 . Back in the laboratory, the sample was re-homogenised and $10.6 \mathrm{~L}$ was transferred into the incubator. Four litres were kept in a second hermetic glass vial, also equipped with a gas purging system. An $8-\mathrm{cm}$ magnetic stirrer was introduced in the incubator, which was closed after a 3-h purge with air to reoxidise completely the fluid mud. Although the in situ temperature was $16.3^{\circ} \mathrm{C}$, the incubator was thermostatically controlled at $20^{\circ} \mathrm{C}$ to limit thermal gradients and changes in gas adsorption/desorption to the vial wall. Throughout the experiment, the extra fluid mud in the second vial was purged at the same frequency with air or nitrogen. Two discrete $60 \mathrm{~mL}$ samples were taken at once from the incubator at variable time intervals with a $60 \mathrm{~mL}$ polypropylene syringe that had been previously filled with fluid mud from the second vial. Therefore, the liquid and gas volumes were constant in the incubator. The content of the syringe was homogenised 6 times with the fluid mud in the incubator before sampling. For DOC samples, fluid mud was centrifuged in pre-combusted glass vials. The supernatant was filtered through pre-combusted $0.7 \mu \mathrm{m}$ glass fibre filters and the filtrates were poisoned with $\mathrm{H}_{3} \mathrm{PO}_{4}$ ( $50 \mu \mathrm{L}$ for $20 \mathrm{~mL}$ of pore water). For all other parameters, centrifugation was done in polypropylene vials and filtration through $0.45 \mu \mathrm{m}$ cellulose acetate filters. The filtrates were then divided into four parts: one conditioned in a serum bottle without headspace and kept at ambient temperature for total alkalinity (TA); one frozen at $-20^{\circ} \mathrm{C}$ for dissolved inorganic nitrogen (DIN) species; one kept at $4{ }^{\circ} \mathrm{C}$ for sulphate $\left(\mathrm{SO}_{4}^{2-}\right)$ and one acidified with a $65 \%$ nitric acid drip for dissolved $\mathrm{Fe}^{2+}$ and $\mathrm{Mn}^{2+}$. 
For anoxic samples, centrifugation, filtration and conditioning were performed under a nitrogen stream to limit oxidation.

The experiment described here was conducted for a total of 27 days. It started under oxic conditions for 6 days with 3 intermediate air purges. At day 7, anoxia was imposed until day 9. Then, oxic conditions were maintained for days 10,11 and 12, with one intermediate purge. From days 13 to 22, anoxia was maintained for 10 days, followed by an injection of $\mathrm{KNO}_{3}$ after 7 days to investigate redox reactions when $\mathrm{Mn}^{2+}$ and nitrate are simultaneously present in anoxic fluid mud pore waters. Finally, from day 23 to 27, oxic conditions were maintained with three intermediate air purges.

\subsection{Analytical techniques}

Analytical techniques for nitrate $\left(\mathrm{NO}_{3}^{-}\right)$, nitrite $\left(\mathrm{NO}_{2}^{-}\right)$, ammonium $\left(\mathrm{NH}_{4}^{+}\right)$, TA, dissolved $\mathrm{Mn}$ and DOC have been described elsewhere (Abril et al., 1999, 2000). Briefly, DIN species were determined with classical spectrocolorimetric techniques, TA by Gran electro-titration with $0.1 \mathrm{~N} \mathrm{HCl}$, performed under a nitrogen stream for anoxic samples, $\mathrm{Mn}^{2+}$ by flame-atomic absorption spectroscopy and DOC with a Shimadzu TOC 5000 analyser. In addition, iron (II) was measured by the ferrozine method (Stookey, 1970) and sulphate was analysed according to a nephelometric method adapted from Rodier (1976), with a precision of about 5\%.

\subsection{Rate calculations}

The rates of production or consumption of any chemical species during the experiment were defined as the loss of, or gain in, the incubation vial (liquid and gas) per volume of fluid mud incubated. For non-gaseous dissolved species $\left(\mathrm{NO}_{3}^{-}, \mathrm{NH}_{4}^{+}\right.$, DIN and $\mathrm{Mn}^{2+}$ ) rates were simply calculated from the slope of the change in concentration versus time. Oxygen consumption rates were determined during steady oxic periods of linear oxygen decrease given by the polarographic electrode in the fluid mud. The total amount of oxygen in the system was calculated at the beginning and at the end of each period between purges, using the concentration measured in the aqueous phase, the volumes of the gas and liquid phases and the temperature and salinity dependence of oxygen solubility given by Benson and Krause (1984), assuming a permanent equilibrium between air and water (Table 1 ). The total amount of oxygen lost in the system was then reported for the water volume and the corresponding time interval. Methane production rates were calculated the same way, except that measurements were done in the gas phase and that the solubility coefficient of methane given by Yamamoto et al. (1976) was used (Table 1). Dissolved inorganic carbon production rates were determined as the sum of the increase in $\mathrm{CO}_{2}$ in the gas phase and DIC in the aqueous phase. The latter was calculated from $p \mathrm{CO}_{2}$ and TA with the constants of carbonic acid from Mehrbach et al. (1973), and the $\mathrm{CO}_{2}$ solubility coefficient from Weiss (1974) (Table 1). Although both calculation modes were consistent at $\pm 7 \%$, calculations based on measured $p \mathrm{CO}_{2}$ and TA were preferred to those based on $\mathrm{pH}$ and TA because drifts of the electrode potentially affected $\mathrm{pH}$

Table 1

Overview of the parameters in the experimental setup.

\begin{tabular}{lc}
\hline Liquid volume $(\mathrm{L})$ & 10.6 \\
Gas volume $(\mathrm{L})$ & 8.6 \\
Liquid and gas temperature $\left({ }^{\circ} \mathrm{C}\right)$ & 20 \\
Liquid salinity & 1.3 \\
$\mathrm{O}_{2}$ solubility coefficient $\left(\mathrm{mmol} \mathrm{kg}^{-1} \mathrm{~atm}^{-1}\right)$ & 1.36 \\
$\mathrm{CO}_{2}$ solubility coefficient $\left(\mathrm{mmol} \mathrm{kg}^{-1} \mathrm{~atm}^{-1}\right)$ & 38.9 \\
$\mathrm{CH}_{4}$ solubility coefficient $\left(\mathrm{mmol} \mathrm{kg}^{-1} \mathrm{~atm}^{-1}\right)$ & 1.54 \\
$\mathrm{~K}_{1}\left[\mathrm{H}_{2} \mathrm{CO}_{3} / \mathrm{HCO}_{3}^{-}\right]\left(\mathrm{mol}^{-1}\right)$ & $4.85 \times 10^{-7}$ \\
$\mathrm{~K}_{2}\left[\mathrm{HCO}_{3}^{-} / \mathrm{CO}_{3}^{2-}\right]\left(\mathrm{mol}^{-1}\right)$ & $8.58 \times 10^{-11}$ \\
\hline
\end{tabular}

measurements. Because DIC production rates relied on the assumption of continuous and total liquid-gas equilibrium, we evaluated the efficiency of the gas-liquid equilibration before starting the experiment. To study this equilibration, tap water was introduced to the system and equilibrated with the gas phase to reach a stable $\mathrm{pCO}_{2}$ value close to $1700 \mathrm{ppmv}$ (Fig. 2). Then, $2 \mathrm{~mL}$ of $1 \mathrm{~N} \mathrm{HCl}$ was introduced through the septum to titrate part of the alkalinity to $\mathrm{CO}_{2}$ and then to measure the rate of $\mathrm{CO}_{2}$ escape to the gas phase. After $\mathrm{HCl}$ injection, $\mathrm{pH}$ rapidly decreased at first and then slowly increased when $\mathrm{CO}_{2}$ escaped to the gas phase. The calculated half-equilibration times during the escape period were $25 \mathrm{~min}$ for $\mathrm{pCO}_{2}$ and $32 \mathrm{~min}$ for $\mathrm{pH}$, respectively. This meant that equilibrium could be assumed only during long periods of stable conditions when $\mathrm{pH}$ and $\mathrm{pCO}_{2}$ varied linearly over periods of several hours. During transient periods following purges or when rapid changes in the $p \mathrm{CO}_{2}$ trend occurred, DIC production rates derived from TA and $p \mathrm{CO}_{2}$ would be affected by any delay in gas equilibration. For the same reason, it was not possible to provide a curve of DIC versus time throughout the whole experiment.

\section{Results}

\subsection{Troubleshooting during the experiment}

The experiment worked well throughout the 27-day period of observation with few exceptions. During days 13 and 14 , at the beginning of the second anoxic period, however, the magnetic stirrer became blocked, which lead to a partial decantation of the fluid mud. As a result, redox conditions in the vial were different at the sampling height than at the electrode height. Because biogeochemical reactions occurred during this period, concentrations are still shown in the results (Figs. 3 and 4). The troubleshooting is indicated by a hashed zone, and the result was not considered for discussion. A second problem occurred during the first few days following the anoxic to oxic switch and was due to a limitation of the incubation technique used: oxidation processes were so intense during these periods that the oxygen electrode could not stabilise (Fig. 3A). In addition, during these reoxidation periods a large part of the $\mathrm{CO}_{2}$ production obviously occurred during the purges with air and most of the $\mathrm{CO}_{2}$ escaped from the system and could not be taken into account in mass balance calculations. Finally, during these reoxidation periods, but after the purge, $\mathrm{pH}$ and $\mathrm{pCO}_{2}$ data suggested that $\mathrm{CO}_{2}$ production was too fast to allow a complete liquid-gas equilibration, and calculated DIC production rates were underestimated as a result. In the following, to describe our data

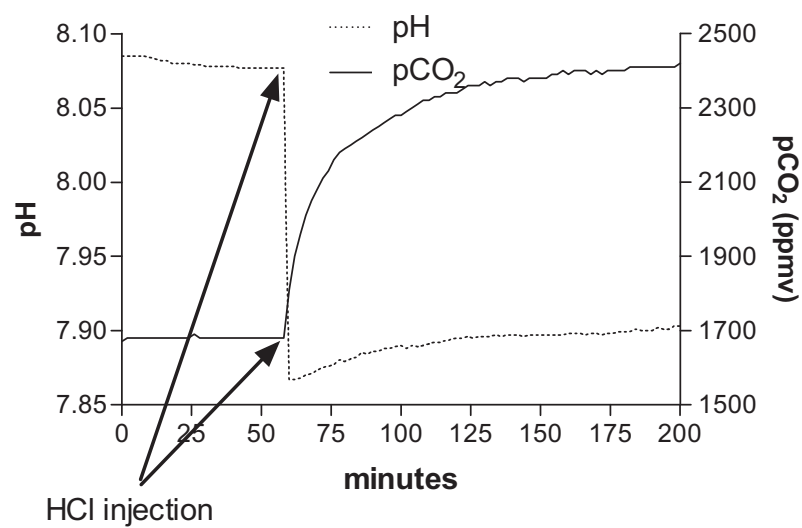

Fig. 2. Equilibration delay between the liquid phase and the gas phase. Temporal evolution of $\mathrm{pH}$ in the liquid phase and $\mathrm{pCO}_{2}$ (ppmv) in the gas phase following a $4.2 \mathrm{mmol}$ injection of $\mathrm{HCl}$. 


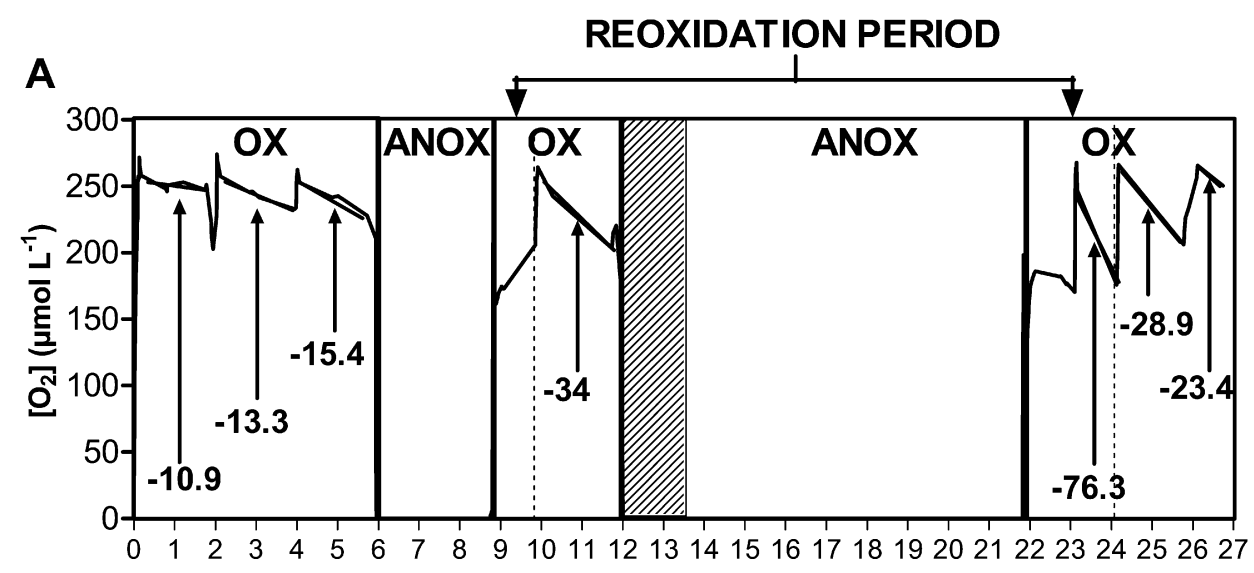

B
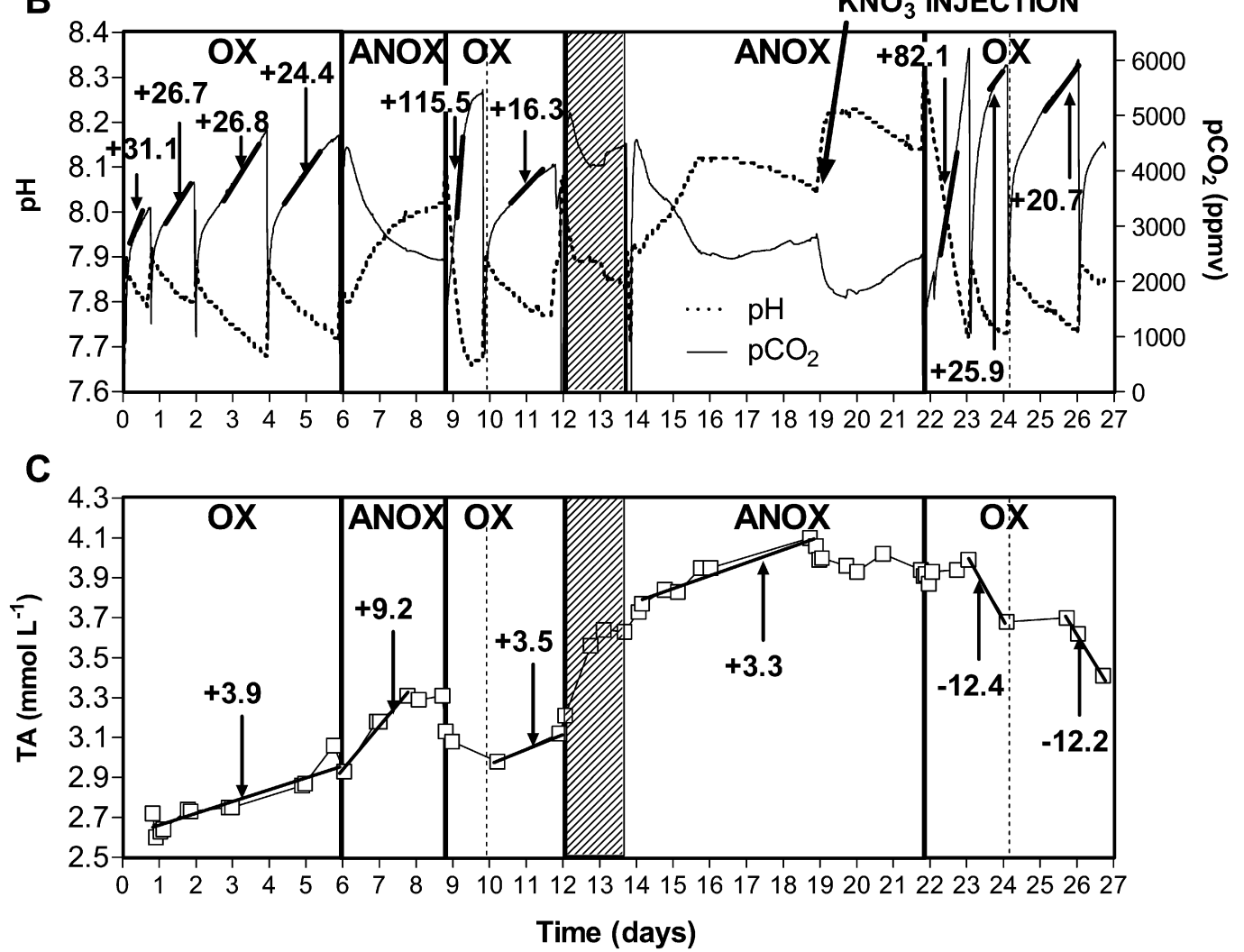

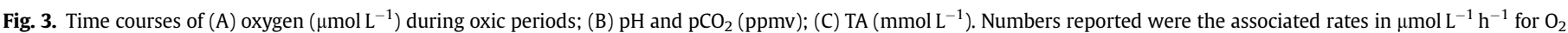

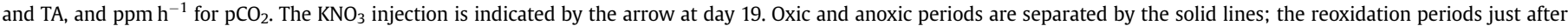
anoxic periods are bordered by the dotted lines. The shaded area corresponds to troubleshooting during the experiment caused by a stop in the stirring.

and in addition to the oxic and anoxic criteria, we used the following definitions for four periods characteristic reproducible throughout the whole experiment. First, "steady oxic periods" referred to stable conditions occurring a few days after oxic conditions were installed, and during these periods concentrations of reduced compounds like $\mathrm{NH}_{4}^{+}$and $\mathrm{Mn}^{2+}$ were null. Secondly, "beginning of anoxic periods" was used to designate the time right after the oxic to anoxic switches when $\mathrm{NO}_{3}^{-}$and $\mathrm{NH}_{4}^{+}$showed extremely rapid changes (decreased and increased, respectively). Third, "steady anoxic conditions" referred to periods later in the anoxia when $\mathrm{NO}_{3}^{-}$remained low and constant. Lastly, the term "reoxidation periods" was used for the transient times just after the oxic to anoxic switches when and $\mathrm{NO}_{3}^{-}$increased and $\mathrm{NH}_{4}^{+}$and $\mathrm{Mn}^{2+}$ decreased very suddenly.

\subsection{Time courses of chemical species throughout the experiment}

During oxic periods, oxygen decreased linearly between purges (Fig. $3 \mathrm{~A}$ ). $\mathrm{O}_{2}$ consumption rates that could be calculated from the measured data varied between 10.9 and $76.3 \mu \mathrm{mol} \mathrm{L}^{-1} \mathrm{~h}^{-1}$ and were always significantly higher after an anoxic period. During the last oxic period in particular, $\mathrm{O}_{2}$ consumption rates progressively decreased between days 24 and 27. Throughout the whole experiment, $\mathrm{pH}$ and $\mathrm{pCO}_{2}$ showed an anti-parallel correlation (Fig. 3B), except during and just after the troubleshooting period (days 13 and 14). This indicated that the liquid and gas phases were close to the equilibrium for $\mathrm{CO}_{2}$. Values of $\mathrm{pH}$ varied between 7.65 and 8.24, except at the beginning of the last oxic period (day 22), when it reached 8.32 at the end of the purge. Values of measured $\mathrm{pCO}_{2}$ 


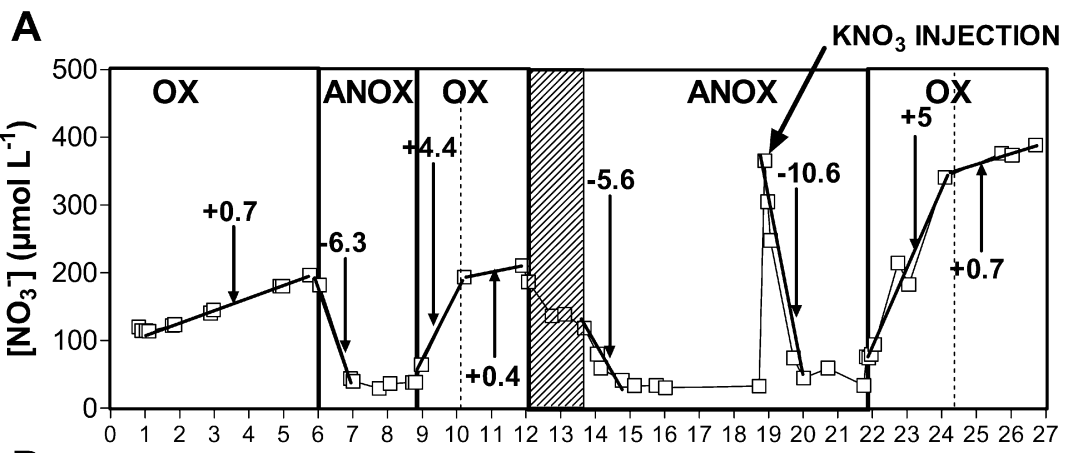

B

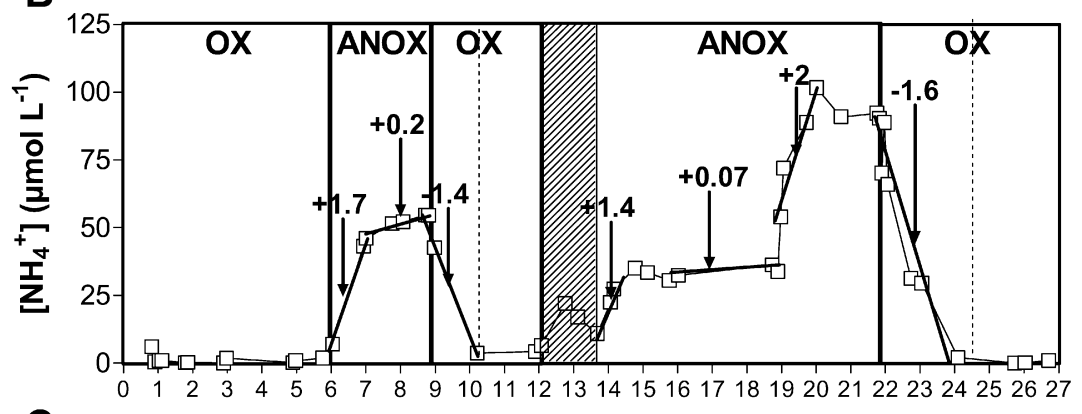

C
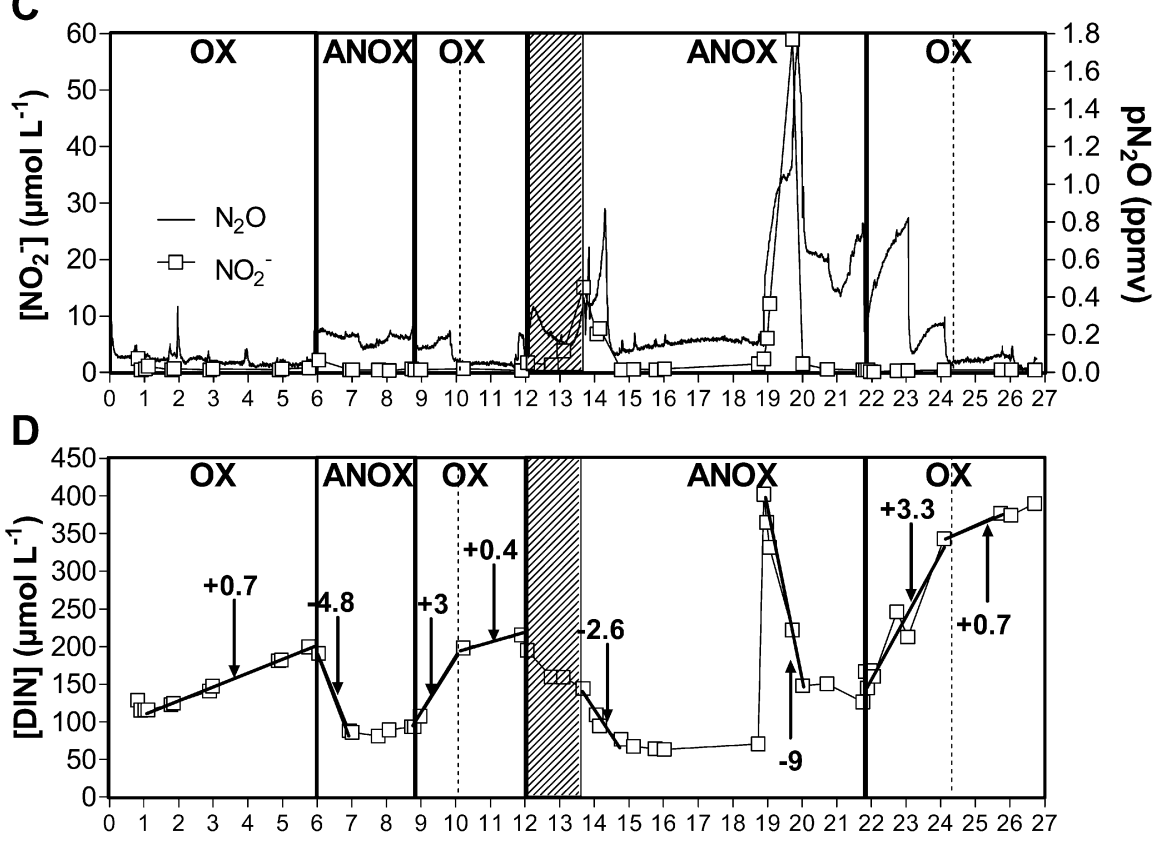

E

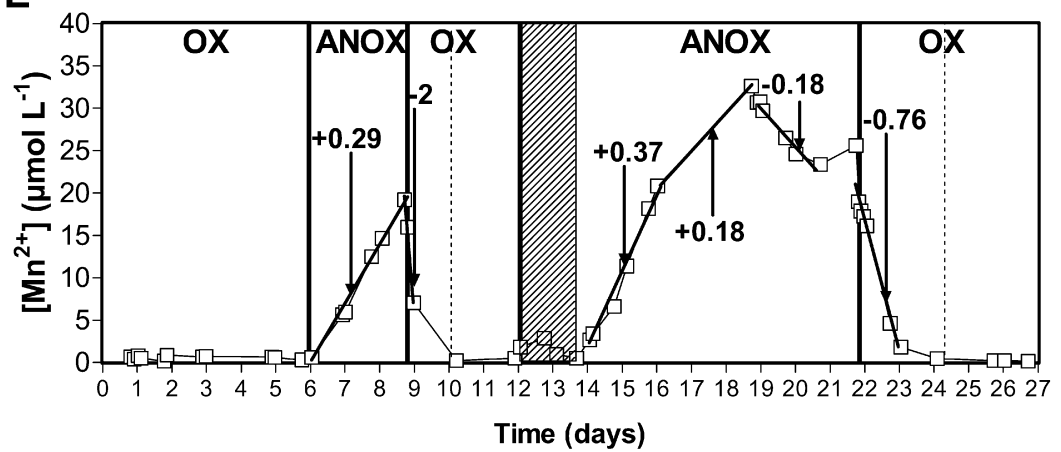

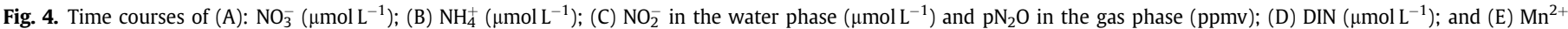
$\left(\mu \mathrm{mol} \mathrm{L} L^{-1}\right)$. Production and consumption rates are expressed in $\mu \mathrm{mol} \mathrm{L}^{-1} \mathrm{~h}^{-1}\left(R^{2}>0.95\right)$. Shaded area same as in Fig. 3. 
varied between 280 and $6220 \mu \mathrm{atm}$. Under oxic conditions, $\mathrm{pCO}_{2}$ increased linearly with aerobic respiration. As TA remained constant or increased, DIC also increased during the oxic periods. DIC production rates that could be calculated from the evolution of $\mathrm{pCO}_{2}$ in the gas phase and TA in the water phase were between 4 and $13 \mu \mathrm{mol} \mathrm{L}^{-1} \mathrm{~h}^{-1}$ during the first oxic period (Table 2), similar but lower than respiration deduced from oxygen during the same period (Fig. 3). DIC production rates calculated during reoxidation periods, and during the second and third oxic periods, were inconsistent with the evolution of oxygen (Table 2). This was probably due to the combined effect of equilibration delays and other processes affecting the $\mathrm{pH}$ and $\mathrm{TA}$ of the water.

During the anoxic periods, $\mathrm{pCO}_{2}$ first decreased (days 7-9 and 15-16), then stabilised (day 17) and finally slowly increased again (days 18-19 and 21-22). The addition of nitrate under anoxic conditions (day 19 in Figs. 3 and 4) rapidly increased the $\mathrm{pH}$ and decreased the $\mathrm{pCO}_{2}$. Throughout the experiment, TA varied between 2.60 and $4.10 \mathrm{mmol} \mathrm{L}^{-1}$ (Fig. 3C) and showed a moderate increase during the first oxic period, followed by rapid increases during anoxic periods (days 7-9 and 13-19). Reoxidation periods (days 10 and 23-24), as well as the day following the nitrate injection (day 19) and the last day of the experiment under oxic conditions (day 27), were all characterised by decreases in TA. Under anoxic conditions, TA increases were concomitant to $\mathrm{pCO}_{2}$ decreases (days 7-9 and 15-16), which resulted in a net positive DIC production. During reoxidation periods (days 9 and 24) sudden TA decreases occurred during the purges with air and the resulting $\mathrm{CO}_{2}$ escape from the system. The following $\mathrm{pCO}_{2}$ increases were extremely fast, partly as the result of a delayed liquid-gas equilibration. As a consequence, DIC production rates during these reoxidation periods could not reasonably be used for the data interpretation. In contrast, after the nitrate injection and without any purge (day 19), both $\mathrm{TA}$ and $\mathrm{pCO}_{2}$ decreased simultaneously even in the absence of any purge, showing a net DIC consumption in the system.

$\mathrm{NO}_{3}^{-}$and $\mathrm{NH}_{4}^{+}$species varied between 30 and $370 \mu \mathrm{mol} \mathrm{L}^{-1}$ and 0 and $110 \mu \mathrm{mol} \mathrm{L}^{-1}$, respectively, and showed a general anti-parallel correlation (Fig. 4A and B). Under steady oxic conditions, $\mathrm{NH}_{4}^{+}$was less than $1 \mu \mathrm{mol} \mathrm{L}^{-1}$ and $\mathrm{NO}_{3}^{-}$increased regularly at rates of 0.4 and $0.7 \mu \mathrm{mol} \mathrm{L}^{-1} \mathrm{~h}^{-1}$ (during days $11-12$, and during days $1-6$ and 25-27, respectively). The first days of the two anoxic periods (days 7 and 14), as well as the day following $\mathrm{KNO}_{3}$ injection (day 19), $\mathrm{NO}_{3}^{-}$ rapidly decreased at rates of $-6.3,-5.6$ and $-10.6 \mu \mathrm{mol} \mathrm{L}^{-1} \mathrm{~h}^{-1}$, respectively. In the same time period, $\mathrm{NH}_{4}^{+}$increased at rates of $+1.7,+1.4$ and $+2 \mu \mathrm{mol} \mathrm{L}^{-1} \mathrm{~h}^{-1}$, respectively. The resulting DIN decreases for the same days were $-4.8,-2.6$. and $-9 \mu \mathrm{mol} \mathrm{L}^{-1} \mathrm{~h}^{-1}$ (Fig. 4D). Later in the anoxic conditions, $\mathrm{NO}_{3}^{-}$stabilised at a constant value around $30 \mu \mathrm{mol} \mathrm{L}^{-1}$ and $\mathrm{NH}_{4}^{+}$increased at much lower rates $\left(0.2 \mu \mathrm{mol} \mathrm{L}^{-1} \mathrm{~h}^{-1}\right.$ for days $8-9$ and $0.07 \mu \mathrm{mol} \mathrm{L}^{-1} \mathrm{~h}^{-1}$ for days 16-18). During the two reoxidation periods (day 10 and days 23-24), $\mathrm{NO}_{3}^{-}$increased extremely fast at rates between 4.4 and $5 \mu \mathrm{mol} \mathrm{L}^{-1} \mathrm{~h}^{-1}$, and $\mathrm{NH}_{4}^{+}$decreased at rates of -1.4 to $-1.6 \mu \mathrm{mol} \mathrm{L}^{-1} \mathrm{~h}^{-1}$.

$\mathrm{NO}_{2}^{-}$was near zero under oxic conditions, but showed some peaks just after the oxic to anoxic switches (Fig. 4C; $2.2 \mu \mathrm{mol} \mathrm{L}^{-1}$ at day 7 and $15.1 \mu \mathrm{mol} \mathrm{L}^{-1}$ at day 14 ). Under anoxic conditions, $\mathrm{NO}_{2}^{-}$ reached $59 \mu \mathrm{mol} \mathrm{L}-1$ at day 20 just after the $\mathrm{KNO}_{3}$ spike and then decreased rapidly to zero. Additionally, $\mathrm{N}_{2} \mathrm{O}$ in the gas phase was less than 0.1 ppmv during steady oxic conditions (days 1-6, 11-12 and 25-27). $\mathrm{N}_{2} \mathrm{O}$ partial pressures were higher under anoxic conditions, as well as during reoxidation periods. In the anoxic conditions, $\mathrm{pN}_{2} \mathrm{O}$ was constant at approximately $0.2 \mathrm{ppmv}$ during days $7-9$ and days $16-19$. A similar value was observed during the first reoxidation period (day 10). Higher values revealed intense $\mathrm{N}_{2} \mathrm{O}$ production after the second oxic to anoxic switch (up to 0.8 ppmv at day 15) and after the $\mathrm{KNO}_{3}$ spike (up to 1.8 ppmv at day 20 ). Finally, $\mathrm{N}_{2} \mathrm{O}$ was also produced during the second reoxidation period (days 23-24) when $\mathrm{pN}_{2} \mathrm{O}$ increased rapidly.

$\mathrm{Mn}^{2+}$ was below $1 \mu \mathrm{mol} \mathrm{L}-1$ under steady oxic conditions and increased under anoxic conditions (Fig. 4E). $\mathrm{Mn}^{2+}$ production started as soon as anoxia was implemented, even in the presence of high concentrations of $\mathrm{NO}_{3}^{-}$. Production rates were linear around $0.3 \mu \mathrm{mol} \mathrm{L}^{-1} \mathrm{~h}^{-1}$ during the first 3 days of anoxia (days 7-9 and 14-16). During reoxidation periods, however, $\mathrm{Mn}^{2+}$ decreased rapidly to zero (rates between -0.76 and $-2 \mu \mathrm{mol} \mathrm{L}^{-1} \mathrm{~h}^{-1}$ ). During the two days after the $\mathrm{KNO}_{3}$ injection in the anoxic conditions (days $20-21), \mathrm{Mn}^{2+}$ decreased at a rate of $-0.18 \mu \mathrm{mol} \mathrm{L}^{-1} \mathrm{~h}^{-1}$. Furthermore, $\mathrm{Fe}^{2+}$ (data not shown) was less than $5 \mu \mathrm{mol} \mathrm{L}^{-1} \mathrm{~h}^{-1}$ (with two peaks at 14.4 and $9.5 \mu \mathrm{mol} \mathrm{L}^{-1}$, but the changes in $\mathrm{Fe}^{2+}$ did not significantly follow the redox conditions) in both oxic and anoxic conditions throughout the whole experiment. Sulphate concentration (not shown) remained constant within the analytical error at $2.1 \mathrm{mmol} \mathrm{L}^{-1}$. Further, the characteristic hydrogen sulphide odour was never perceived in any of the samples studied.

Table 2

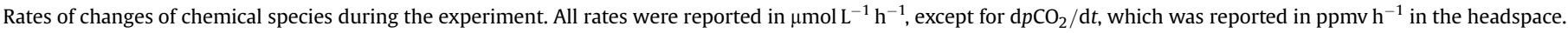

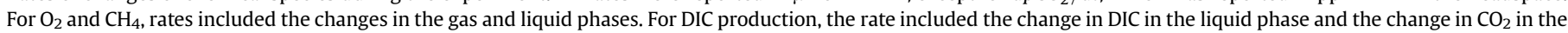
gas phase (see text).

\begin{tabular}{|c|c|c|c|c|c|c|c|c|c|c|c|c|}
\hline Days & $\mathrm{O}_{2}$ cons. & DIC prod. & RQ & $\mathrm{d} p \mathrm{CO}_{2} / \mathrm{d} t$ & $\mathrm{~d}[\mathrm{TA}] / \mathrm{d} t$ & $\mathrm{CH}_{4}$ prod & $\mathrm{d}\left[\mathrm{NO}_{3}^{-}\right] / \mathrm{d} t$ & $\mathrm{~d}\left[\mathrm{NH}_{4}^{+}\right] / \mathrm{d} t$ & $\mathrm{~d}\left[\mathrm{Mn}^{2+}\right] / \mathrm{d} t$ & $\mathrm{~d}[\mathrm{DIN}] / \mathrm{d} t$ & $\mathrm{O}_{2} / \mathrm{DIN}$ & DIC/DIN \\
\hline $1-2$ ox & 10.9 & 9 & 0.82 & +26.7 & +3.9 & 0 & +0.7 & 0 & 0 & +0.7 & 15 & 13 \\
\hline $3-4$ ox & 13.3 & 7.1 & 0.53 & +26.8 & +3.9 & 0 & +0.7 & 0 & 0 & +0.7 & 19 & 11 \\
\hline $5-6$ ox & 15.4 & 12 & 0.78 & +24.4 & +3.9 & 0 & +0.7 & 0 & 0 & +0.7 & 22 & 17 \\
\hline 7 anox & - & 8.6 & - & -61.1 & +9.2 & 0.012 & -6.3 & +1.7 & +0.29 & -4.8 & - & - \\
\hline 8 anox & - & 1.3 & - & -12.1 & +0.1 & 0.012 & -0.02 & +0.2 & +0.29 & +0.18 & - & 7 \\
\hline $10 \mathrm{ox}$ & $a_{-}$ & b,c 11.7 & - & +115.5 & c -15.7 & 0 & +4.4 & -1.4 & -2.0 & +3.0 & $a_{-}$ & b ${ }^{\mathrm{c}} 4$ \\
\hline $11-12$ ox & a33.8 & ${ }^{\mathrm{b}} 4.6$ & 0.12 & +16.3 & +3.5 & 0 & +0.4 & 0 & 0 & +0.4 & ${ }^{\mathrm{a}} 82$ & ${ }^{\mathrm{a}} 10$ \\
\hline 15 anox & - & 2.4 & - & -54.2 & +3.3 & 0.019 & -5.6 & +1.4 & +0.37 & -2.6 & - & - \\
\hline 16 anox & - & 2.4 & - & -54.2 & +3.3 & 0.019 & 0 & +0.07 & +0.37 & 0.07 & - & 34 \\
\hline 17-19 anox & - & 0.6 & - & +4.2 & +3.3 & 0.019 & 0 & +0.07 & +0.18 & 0.07 & - & 8 \\
\hline 20 spike & - & - & - & -101.2 & ${ }^{c}-5.1$ & 0 & -10.6 & +2 & -0.18 & -8.6 & - & - \\
\hline 21 anox & - & 4.0 & - & +10.6 & -0.1 & 0 & -0.25 & +0.05 & +0.02 & -0.2 & - & - \\
\hline $22-23$ ox & $a_{-}$ & ${ }^{\mathrm{b}} 23.1$ & - & +82.1 & +0.1 & 0 & +5.0 & -1.6 & -0.76 & +3.3 & $a_{-}$ & ${ }^{b} 7$ \\
\hline 24 ox & ${ }^{\mathrm{a}} 76$ & ${ }^{\mathrm{c}} 11.1$ & ${ }^{\mathrm{c}} 0.14$ & +25.9 & -12.4 & 0 & +5.0 & -1.6 & 0 & +3.3 & 23 & ${ }^{\mathrm{c}} 4$ \\
\hline 25 ox & 29 & 18.2 & 0.62 & +20.7 & +0.1 & 0 & +0.7 & 0 & 0 & +0.7 & 41 & 26 \\
\hline 26 ox & 23 & c_- & $c_{-}$ & +27.3 & -12.2 & 0 & +0.7 & 0 & 0 & +0.7 & 32 & c_- \\
\hline
\end{tabular}

${ }^{a}$ Rates totally (not shown) or potentially affected by drifts of the $\mathrm{O}_{2}$ electrode.

b Rates likely underestimated because of a delay in water-gas equilibration of $\mathrm{CO}_{2}$ and because some $\mathrm{CO}_{2}$ escaped the incubation vial during purges.

c Rates affected by large TA changes likely due to carbonate dissolution/precipitation. 

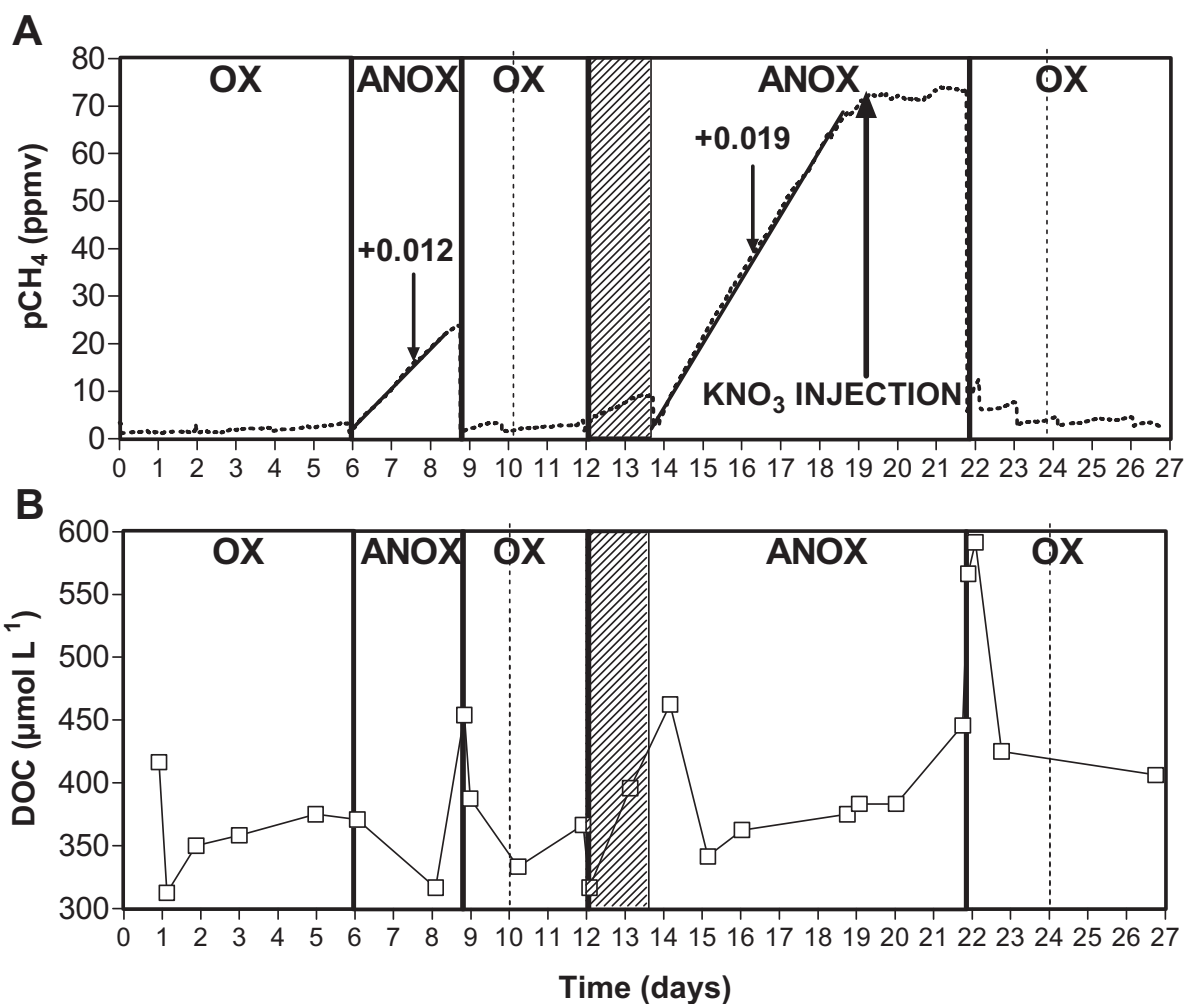

Fig. 5. Time courses of (A) $\mathrm{pCH}_{4}(\mathrm{ppmv})$ in the gas phase and calculated methane production rates $\left(\mu \mathrm{mol} \mathrm{L}^{-1} \mathrm{~h}^{-1}\right)$; (B) dissolved organic carbon ( $\mu$ mol $\mathrm{L}^{-1}$ )

Finally, methane started to increase in the gas phase as soon as anoxia was implemented (Fig. 5A), even in the presence of $\mathrm{NO}_{3}^{-}$, and at a fairly constant rate of $0.012-0.019 \mu \mathrm{mol} \mathrm{L}^{-1} \mathrm{~h}^{-1}$. The $\mathrm{KNO}_{3}$ addition immediately stopped the $\mathrm{CH}_{4}$ production at day 19 . When purging with air to create the oxic conditions, $\mathrm{CH}_{4}$ was removed from the gas phase and was no longer detected in the oxic conditions. DOC was observed to vary between 313 and $592 \mu \mathrm{mol} \mathrm{L}^{-1}$. The highest values appeared just after the anoxic to oxic switches (days 9 and 23), as well as after the troubleshooting at day 14 .

\section{Discussion}

Temporal changes of chemical species, and the rates of these changes during the experiment, gave significant new information on the biogeochemical processes occurring during oxic/anoxic oscillations in fluid mud. Here, we first discussed the nature of processes occurring in anoxic and oxic conditions during the experiment. Next, we carefully analysed the data to perform a mass balance calculation to evaluate the rates of the various reactions involved and the impact of redox oscillation on OM mineralisation.

\subsection{Processes in anoxic conditions}

The fact that iron(II) and sulphate did not significantly change during the incubation revealed that, in contrast to DMM, where iron is the major oxidant (Aller, 1998), suboxic conditions in the estuarine fluid mud were dominated by the reactions in which nitrate, ammonium and manganese are involved (Abril et al., 1999, 2000). Methanogenesis also occurred, but it represented a minor part of the organic carbon mineralisation, with a $\mathrm{CH}_{4}$ production rate of less than $20 \mathrm{nmol} \mathrm{L}^{-1} \mathrm{~h}^{-1}$ (Fig. 5, Table 2), compared to rates around $1-20$ and $0.1-5 \mu \mathrm{mol} \mathrm{L}^{-1} \mathrm{~h}^{-1}$ for carbon and nitrogen, respectively (Table 2 ). There were two contrasting periods during the anoxic conditions: the first days after the oxic to anoxic switch

Table 3

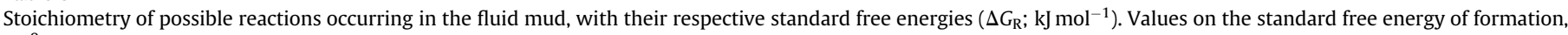
$\Delta G_{\mathrm{f}}^{0}$, were taken from Wagman et al. (1982) and Stumm and Morgan (1996).

\begin{tabular}{|c|c|}
\hline Reaction & $\Delta G^{0}\left(\mathrm{~kJ} \mathrm{~mol}^{-1}\right)$ \\
\hline 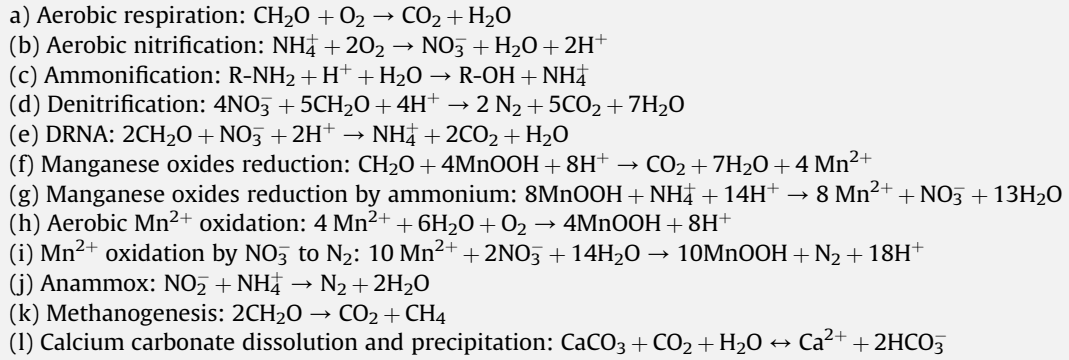 & $\begin{array}{r}-478.9 \\
-299.1 \\
-2423.7 \\
-688.7 \\
-583.2 \\
-586.5 \\
143.7 \\
380.3 \\
-357.7 \\
-139.9\end{array}$ \\
\hline
\end{tabular}


showed a very fast $\mathrm{NO}_{3}^{-}$decrease and $\mathrm{NH}_{4}^{+}$increase, until the nitrate concentration stabilised at $\sim 30 \mu \mathrm{mol} \mathrm{L}^{-1}$. Later, with steady anoxic conditions achieved, $\mathrm{NO}_{3}^{-}$concentrations were constant and low and $\mathrm{NH}_{4}^{+}$continued to increase, but at a much lower rate. The fast production of $\mathrm{NH}_{4}^{+}$at the beginning of the anoxic period (days 7, 15 and 19 , just after the $\mathrm{KNO}_{3}$ spike) could have been the result of ammonification (reaction c in Table 3 ) and dissimilatory reduction of nitrate to ammonium (DRNA, reaction e). During these initial periods of anoxia, the production of $\mathrm{NH}_{4}^{+}$was between 1.4 and $1.7 \mu \mathrm{mol} \mathrm{L}^{-1} \mathrm{~h}^{-1}$, and the DIC production was between 2.4 and $8.6 \mu \mathrm{mol} \mathrm{L}^{-1} \mathrm{~h}^{-1}$ (Table 2). The resulting $\mathrm{DIC} / \mathrm{NH}_{4}^{+}$production ratio was 1.7-5.1, which appeared to be too low to result from ammonification alone because the POM in the Gironde had a C/N ratio around 10 (Middelburg and Herman, 2007). In addition, heterotrophic organism needed to uptake DIN (Middelburg and Nieuwenhuize, 2000), which meant that the $\mathrm{C} / \mathrm{N}$ ratio at which $\mathrm{OM}$ is mineralised must be even higher than 10 . Consequently OM mineralisation alone could not account for the fast $\mathrm{NH}_{4}^{+}$production at the beginning of the anoxic periods. The significance of DRNA as a $\mathrm{NH}_{4}^{+}$source was also attested to by the value of the $\mathrm{NH}_{4}^{+}$ production rate, $\mathrm{dNH}_{4}^{+} / \mathrm{d} t$, calculated for each measurement interval and being a function of $\mathrm{NO}_{3}^{-}$concentration during the beginning of the anoxic periods (Fig. 6B). This suggested that during these periods, $\mathrm{NH}_{4}^{+}$originates in part from the reduction of $\mathrm{NO}_{3}^{-}$by DRNA. Several previous works have pointed out that DRNA can consume between 7 and 98\% of nitrate in coastal sediments with a high OM content (Gilbert et al., 1998; Kelly-Gerreyn et al., 2001).

The increase in $\mathrm{Mn}^{2+}$ was linear and independent of $\mathrm{NH}_{4}^{+}$ concentration during each anoxic period, which suggested dissimilatory Mn-reduction (reaction f) occurred dominantly, and Mn-reduction by ammonium was minor (reaction $\mathrm{g}$ ), as previously interpreted from in situ profiles (Abril et al., 1999).

During steady anoxic periods, nitrate concentration remained around $30 \mu \mathrm{mol} \mathrm{L}^{-1}$, which revealed that both denitrification and DRNA were stopped when $\mathrm{NO}_{3}^{-}$concentration reached this threshold concentration (Fig. 4A and $\mathrm{B}$ ). This incomplete nitrate consumption was contradictory to measurements made in the Gironde fluid mud, where $\mathrm{NO}_{3}^{-}$concentration was zero when the SPM concentration reached $250 \mathrm{~g} \mathrm{~L}^{-1}$ (Abril et al., 2000). The SPM concentration of the fluid mud during our experiment was $140 \mathrm{~g} \mathrm{~L}^{-1}$. Perhaps, in contrast to in situ conditions in the fluid mud of the highly turbulent conditions of the incubation, bacteria fixed on particles and performing denitrification and DRNA, could not use dissolved $\mathrm{NO}_{3}^{-}$at a concentration below $30 \mu \mathrm{mol} \mathrm{L}^{-1}$. An alternative explanation was that nitrate consumption was balanced by nitrate production during these periods. Anoxic $\mathrm{NO}_{3}^{-}$ production has been observed in several marine sediment cores (Anschutz et al., 2000, 2002; Deflandre et al., 2000, 2002; Mortimer et al., 2004) and in vitro incubations of sediment (Hulth et al., 1999; Anschutz et al., 2005; Chaillou et al., 2007). $\mathrm{NO}_{3}^{-}$ could have been produced from anoxic oxidation of $\mathrm{NH}_{4}^{+}$using $\mathrm{Mn}$ (III, IV) oxides as the electron acceptor (reaction g). There was no evidence, however, of such processes occurring in the fluid mud, as the $\mathrm{Mn}^{2+}$ production rates remained very linear throughout the entire anoxic period (Fig. 4E). Anaerobic oxidation of $\mathrm{NH}_{4}^{+}$in the presence of $\mathrm{NO}_{2}^{-}$(anammox, reaction $\mathrm{j}$ ) has also been recognised as an alternative pathway for benthic $\mathrm{N}_{2}$ production in several anoxic aquatic environments (Dalsgaard and Thamdrup, 2002; Trimmer et al., 2003; Rysgaard et al., 2004). During our experiment, a $\mathrm{NO}_{2}^{-}$peak of $60 \mu \mathrm{mol} \mathrm{L}-1$ appeared just after the $\mathrm{NO}_{3}$ spike during the anoxic period (Fig. 4, days 19). Then, the $\mathrm{NO}_{2}^{-}$concentration dropped back to zero while the $\mathrm{NH}_{4}^{+}$concentration kept increasing steadily. Accordingly, this suggested that the anammox process was minor.
The evolution of DIN species after the $\mathrm{KNO}_{3}$ injection, and under prolonged anoxic conditions, followed a pattern similar to what we observed at the beginning of the anoxic period (Figs. 4 and 6). Both consumption of $\mathrm{NO}_{3}^{-}$and production of $\mathrm{NH}_{4}^{+}$showed the same dependency on $\mathrm{NO}_{3}^{-}$concentration as at the beginning of the anoxic periods (Fig. 6A and C). However, $\mathrm{Mn}^{2+}$, DIC and TA had very different behaviours, as their concentrations decreased after the injection and increased at the beginning of each "normal" anoxic period (Figs. 3 and 4). After the $\mathrm{KNO}_{3}$ injection, the concomitant high concentrations of $\mathrm{NO}_{3}^{-}$and $\mathrm{Mn}^{2+}$ possibly allowed the oxidation of $\mathrm{Mn}^{2+}$ with $\mathrm{NO}_{3}^{-}$to either $\mathrm{N}_{2}$ (reaction i) or $\mathrm{NH}_{4}^{+}$ (reaction h) (Luther et al., 1997; Hulth et al., 1999). These two reactions produced protons, and therefore, potentially decreased the TA, as was observed in the experiment. However, this alone could not explain the TA decrease because DRNA and denitrification occurred simultaneously and involved many more protons $\left(+2 \mu \mathrm{mol} \mathrm{L}^{-1} \mathrm{~h}^{-1} \mathrm{NH}_{4}^{+}\right.$produced and $-10 \mu \mathrm{mol} \mathrm{L}^{-1} \mathrm{~h}^{-1} \mathrm{NO}_{3}^{-}$ consumed, compared to $-0.18 \mu \mathrm{mol} \mathrm{L}^{-1} \mathrm{~h}^{-1} \mathrm{Mn}^{2+}$ consumed). These observations should have resulted in a net TA increase, according to the stoichiometry in Table 3, as was the case at the beginning of each anoxic period (Fig. 3C). An alternative and more plausible explanation was that the removal of $\mathrm{Mn}^{2+}$ was the result
A
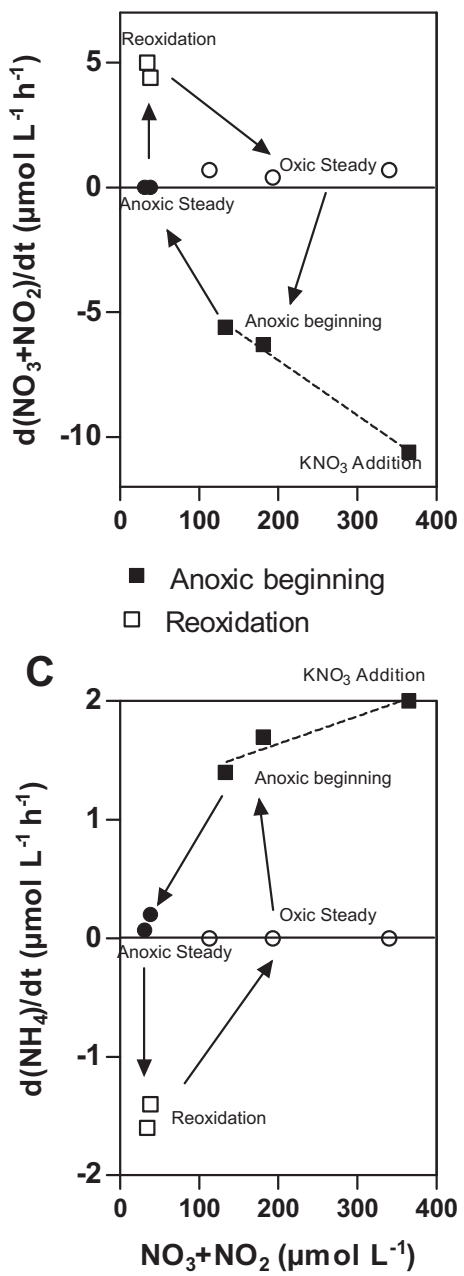

B

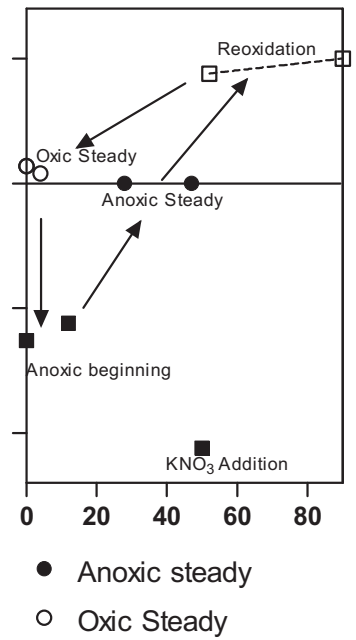

D

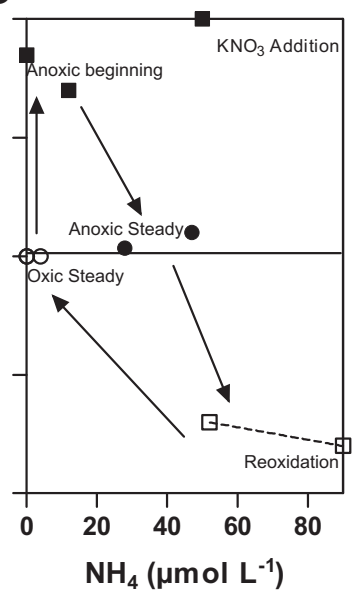

Fig. 6. Relationship between the inorganic nitrogen species concentrations ( $\mu \mathrm{mol} \mathrm{L}^{-1}$ ) and the transformation rates $\left(\mu \mathrm{mol} \mathrm{L}{ }^{-1} \mathrm{~h}^{-1}\right)$. (A) Change in $\mathrm{NO}_{3}^{-}+\mathrm{NO}_{2}^{-}$versus the $\mathrm{NO}_{3}^{-}+\mathrm{NO}_{2}^{-}$concentration; (B) change in $\mathrm{NO}_{3}^{-}+\mathrm{NO}_{2}^{-}$versus the $\mathrm{NH}_{4}^{+}$concentration; (C) change in $\mathrm{NH}_{4}^{+}$versus the $\mathrm{NO}_{3}^{-}+\mathrm{NO}_{2}^{-}$concentration; and (D) change in $\mathrm{NH}_{4}^{+}$versus the $\mathrm{NH}_{4}^{+}$concentration. 
of precipitation associated with carbonates. Indeed, after the $\mathrm{KNO}_{3}$ injection, concomitant TA and pCO2 decreases occurred (Fig. 3). Such DIC consumption could only be attributed to carbonate precipitation (reaction $\mathrm{k}$ ), which very likely occurred at that time as the $\mathrm{pH}$ reached 8.32. Dissolved manganese was most likely precipitated as a mixed calcium-manganese carbonate (Middelburg et al., 1987; Mucci, 1988).

The occurrence of methanogenesis in the presence of electron acceptors has been reported in several coastal sediments and was due to the presence of non-competitive organic substrates that are preferentially used by methanogens (Oremland and Polcin, 1982). This might be a reason why, before the $\mathrm{KNO}_{3}$ injection, methanogenesis happened in the presence of $\mathrm{NO}_{3}^{-}$(Figs. 4 and 5). Organic substrate concentrations were probably sufficient in the system for both denitrification and methanogenesis to occur together. Methanogenesis, however, was suddenly stopped just after the injection of nitrate. There might be three reasons for this observation. First, denitrifying bacteria that could compete with methanogenic bacteria could have suddenly consumed the available substrates after injection, which would have stopped methanogenesis (Clarens et al., 1998). Second, $\mathrm{N}_{2} \mathrm{O}$ concentrations were very high after the injection and this compound was known to be toxic for methanogens (Roy and Conrad, 1999). Finally, methane could have been suddenly oxidised with the added nitrate by anaerobic methanotrophic bacteria, as pointed out recently for anoxic fresh water environments (Raghoebarsing et al., 2006).

\subsection{Processes in oxic conditions}

Under oxic conditions, no loss of nitrogen as $\mathrm{N}_{2}$ could occur and the DIN increase represented the net ammonification rate. During steady oxic conditions, $\mathrm{NH}_{4}^{+}$concentrations remained close to zero (Fig. 4), and nitrification was controlled by the supplied $\mathrm{NH}_{4}^{+}$from ammonification. In contrast, during reoxidation periods, the high initial concentration of $\mathrm{NH}_{4}^{+}$made the $\mathrm{NO}_{3}^{-}$gain $\left(4.4-5 \mu \mathrm{mol} \mathrm{L}^{-1} \mathrm{~h}^{-1}\right)$ higher than the $\mathrm{NH}_{4}^{+}$loss $\left(-1.4\right.$ to $\left.-1.6 \mu \mathrm{mol} \mathrm{L}^{-1} \mathrm{~h}^{-1}\right)$ (Fig. 4 and Table 2 ), with both rates being correlated to $\mathrm{NH}_{4}^{+}$concentrations (Fig. 6B and $\mathrm{E}$ ). During reoxidation, one part of the nitrification occurred using the $\mathrm{NH}_{4}^{+}$initial pool and another part using $\mathrm{NH}_{4}^{+}$supplied simultaneously by ammonification. The fact that the DIN increase was much larger during the reoxidation periods $\left(3-3.3 \mu \mathrm{mol} \mathrm{L}^{-1} \mathrm{~h}^{-1}\right)$ than during the steady oxic periods (0.4-0.7 $\mu \mathrm{mol} \mathrm{L}^{-1} \mathrm{~h}^{-1}$ ) (Fig. 4D and Table 2), gave evidence that OM mineralisation was much more intense during the reoxidation periods.

In addition to the nitrogen data, other evidence for an enhancement of $\mathrm{OM}$ mineralisation during reoxidation periods came from the carbon and oxygen data, although these were less quantitative. Indeed, carbon mineralisation was difficult to evaluate clearly because of some experimental limitations and the fact that chemical species were affected by a number of different processes. TA showed a decreasing trend during most reoxidation periods and also during the last days of the experiment, but an increasing trend during the two periods of steady oxic conditions (days 2-5 and 11-12 in Fig. 3C, Table 2). TA decreases during reoxidation could be attributed to the release of protons by nitrification and $\mathrm{Mn}^{2+}$ precipitation (reactions $b$ and $h$ ). During steady oxic periods, nitrification coupled to ammonification could have slightly decreased the TA at a rate equal to the DIN increase (Abril and Frankignoulle, 2001), i.e., at -0.7 and $-0.4 \mu \mathrm{mol} \mathrm{L}^{-1} \mathrm{~h}^{-1}$ at days $2-5$ and $11-12$, respectively (Table 2 ). Instead, TA increased at rates of 3.3 and $3.5 \mu \mathrm{mol} \mathrm{L}^{-1} \mathrm{~h}^{-1}$, respectively. Carbonate dissolution (reaction $\mathrm{k}$ ) coupled to respiration was the most probable reason for this net TA production during steady oxic phases, a process already evoked for explaining in situ TA distribution in Gironde and
Loire estuaries (Abril et al., 1999, 2003, 2004). When carbonate dissolution was coupled to aerobic respiration, one half of the TA produced originated from OM mineralisation and the other part from calcium carbonate. In our experimental setup, the $\mathrm{CO}_{2}$ produced by aerobic respiration could have been involved in the dissolution reaction before the equilibration with the headspace was complete (Fig. 2). This TA production increased the buffer capacity of the carbonate system and might have slowed down $\mathrm{CO}_{2}$ degassing to the headspace. During carbonate dissolution, the DIC production was not only related to OM mineralisation, but it might also have been underestimated due to gas equilibration.

The extremely high $\mathrm{pCO}_{2}$ raises and the strong drift of the polarographic electrode immediately after anoxic to oxic switches both suggested an enhanced OM mineralisation during reoxidation. The oxygen consumption that could be calculated increased very significantly after anoxic periods (Table 2). For an unknown reason, this enhancement of the oxygen consumption following anoxic periods lasted longer than the enhancement of the DIN production (Figs. $3 \mathrm{~A}$ and $4 \mathrm{~A}$, Table 2). DIC production rates, when they could be calculated, also showed this trend, with a maximum value of $23 \mu \mathrm{mol} \mathrm{L}{ }^{-1} \mathrm{~h}^{-1}$ at days 22-23 (Table 3). In several cases, however, TA decreased after the oxic to anoxic switches (Fig. 3C) due to the reoxidation of various reduced compounds that produced protons. This observation was probably also partly due to the precipitation of calcium carbonate when $\mathrm{pH}$ rose during the purge with air. Besides these methodological limitations, carbon mineralisation rates in oxic conditions derived from DIC production or oxygen consumption were consistently higher after prolonged periods of anoxia (Table 2).

Finally, the DOC signal throughout the experiment (Fig. 5B) also supported an enhancement of OM mineralisation during reoxidation. If the first data point was excluded (which in fact also corresponded to a reoxidation, but from in situ conditions), as well as the data just after the troubleshooting, DOC concentrations were $509 \pm 82 \mu \mathrm{mol} \mathrm{L}^{-1}$ during the reoxidation periods (days 9 and 23) and $365 \pm 34 \mu \mathrm{mol} \mathrm{L}^{-1}$ the remainder of the experimental time. As $\mathrm{DOC}$ was generally an intermediate product during particulate $\mathrm{OM}$ mineralisation to $\mathrm{CO}_{2}$ (e.g., Kristensen et al., 1995), the temporary DOC accumulation observed here suggested that the conversion of POC to DOC became faster than the conversion of DOC to $\mathrm{CO}_{2}$. Additionally, the excess of $100-250 \mu \mathrm{mol} \mathrm{L}^{-1}$ of DOC found during these periods was extremely labile, as it rapidly disappeared a few hours later. It was also probable that the background DOC of $365 \mu \mathrm{mol} \mathrm{L}^{-1}$ that remained relatively constant throughout the whole experiment corresponded to a relatively refractory pool. Except during reoxidation periods, the supply of labile DOC from POC through exo-enzymatic activity or fermentative processes (Kristensen et al., 1995; Sun et al., 2002) probably strongly controlled the final rate of OM mineralisation. In contrast, the supply of labile DOC was enhanced during reoxidation, but it took some hours for the heterotrophic bacterial metabolism to respond and convert the available labile $\mathrm{DOC}$ to $\mathrm{CO}_{2}$ and biomass.

\subsection{Mass balance calculations}

As a final objective to evaluate OM mineralisation rates, a simple model analysis of our experimental data was performed. The most robust rates were those derived from no gaseous species, i.e., $\mathrm{NO}_{3}^{-}$, $\mathrm{NH}_{4}^{+}$, DIN and $\mathrm{Mn}^{2+}$. Dominant reactions affecting $\mathrm{OM}$ and these species were aerobic respiration, nitrification, ammonification, denitrification, DRNA and Mn reduction. We could write for oxic conditions:

$\frac{\mathrm{d}\left[\mathrm{NO}_{3}^{-}\right]}{\mathrm{d} t}=R_{\mathrm{NIT}}$ and $\frac{\mathrm{d}[\mathrm{DIN}]}{\mathrm{d} t}=R_{\mathrm{AM}}$ 
where $R_{\mathrm{NIT}}$ and $R_{\mathrm{AM}}$ are the nitrification and ammonification rates, respectively.

For anoxic conditions:

$\frac{\mathrm{d}\left[\mathrm{NO}_{3}^{-}\right]}{\mathrm{d} t}=-R_{\mathrm{DNRA}}-R_{\mathrm{DENIT}}, \frac{\mathrm{d}\left[\mathrm{NH}_{4}^{+}\right]}{\mathrm{d} t}=R_{\mathrm{AM}}-R_{\mathrm{DNRA}}$

and

$\frac{1}{4} \frac{\mathrm{d}\left[\mathrm{Mn}^{2+}\right]}{\mathrm{d} t}+\frac{5}{4} R_{\mathrm{DENIT}}+2 R_{\mathrm{DNRA}}=\frac{\mathrm{C}}{\mathrm{N}} R_{\mathrm{AM}}$

where $R_{\mathrm{DENIT}}, R_{\mathrm{DNRA}}$ and $R_{\mathrm{AM}}$ are the denitrification, DNRA and ammonification rates, respectively, and $\mathrm{C} / \mathrm{N}$ is an assumed $\mathrm{C} / \mathrm{N}$ molar ratio for OM mineralisation.

In both the oxic and anoxic conditions, the rate of carbon mineralisation, $R_{\mathrm{C}-\mathrm{MIN}}$, was related to the rate of ammonification according to the equation $R_{\mathrm{C}-\mathrm{MIN}}=\mathrm{C} / \mathrm{N} R_{\mathrm{AM}}$.

All rates could be calculated in this study if a $\mathrm{C} / \mathrm{N}$ ratio was assumed. The $\mathrm{C} / \mathrm{N}$ ratio of POM in the Gironde ETM was about 10 , but the one for OM mineralisation could be higher, due to nitrogen uptake by heterotrophic bacteria (Middelburg and Nieuwenhuize, 2000). During the experiments, the ratio of $\mathrm{O}_{2}$ consumption / DIN increased in the range between 15 and 41, excluding a rate potentially affected by electrode drift at days 11 and 12. DIC/DIN production ratios not affected by gas equilibration delays or large alkalinity changes were between 8 and 34 . We have thus tested the dependency of calculated rates for $\mathrm{C} / \mathrm{N}$ values between 10 and 40 . This was particularly important at the beginning of anoxic periods, when denitrification, DNRA and ammonification occurred simultaneously. Fig. 7 describes the sensitivity of these three modelled rates to the $C / N$ ratio during the periods of initial anoxia conditions. Modelled $R_{\mathrm{AM}}$ and $R_{\mathrm{DNRA}}$ were quite sensitive to the $\mathrm{C} / \mathrm{N}$ ratio, decreasing respectively by $74 \%$ and increasing by $80 \%$. Modelled $R_{\text {DENIT }}$ and $R_{\text {C-MIN }}$, on the other hand, were much less sensitive, decreasing by $11 \%$ and increasing by $6 \%$, respectively (Table 4 ). During the three other characteristic periods, $R_{\mathrm{AM}}$ was accurately obtained from the DIN increase and was independent of the $\mathrm{C} / \mathrm{N}$ ratio. In contrast, modelled $R_{\mathrm{C} \text {-MIN }}$ was very sensitive (proportional) to the $\mathrm{C} / \mathrm{N}$ ratio. Despite the uncertainty in the rates presented in Table 4, significantly different rates could be observed for different periods. For example, $R_{\mathrm{AM}}$ and $R_{\mathrm{C}-\mathrm{MIN}}$ were significantly higher during reoxidation than during oxic steady state, than during steady anoxic conditions. However, beginning anoxic and steady oxic periods did not show significantly different modelled $\mathrm{R}_{A M}$ and $\mathrm{R}_{C-M I N}$.

\subsection{Impact of redox oscillations on OM mineralisation rates}

Several works based on in vitro experiments have investigated the impact of redox oscillations induced either by bioturbation or resuspension on sedimentary OM degradation. There is now clear evidence that for relatively refractory land-derived OM, aerobic respiration is almost always faster than anaerobic respiration (Aller, 1994, 1998; Kristensen et al., 1995; Andersen, 1996; Hulthe et al., 1998). This was also the case in our experiment as confirmed by

Table 4

Results of calculated rates during the four characteristic periods. When a range was given, it resulted from the assumption of two $\mathrm{C} / \mathrm{N}$ ratios of 10 and 40 for $\mathrm{OM}$ mineralisation.

\begin{tabular}{lllllr}
\hline & $R_{\mathrm{DENIT}}$ & $R_{\mathrm{DNRA}}$ & $R_{\mathrm{AM}}$ & $R_{\mathrm{NIT}}$ & \multicolumn{1}{c}{$R_{\mathrm{C}-\mathrm{MIN}}$} \\
\hline Oxic steady & 0.0 & 0.0 & 0.7 & 0.7 & $7-28$ \\
Anoxic beginning & $4.6-5.2$ & $0.7-1.3$ & $0.2-0.8$ & 0.0 & $8.1-8.5$ \\
Anoxic steady & 0.0 & 0.0 & 0.1 & 0.0 & $1.0-4.0$ \\
Reoxidation & 0.0 & 0.0 & 3.2 & 4.8 & $32-128$ \\
\hline
\end{tabular}

both $\mathrm{C}$ and $\mathrm{N}$ mass balances (Table 3). Additionally, an accumulation of DOC occurred under anoxic conditions and this DOC was rapidly degraded under oxic conditions (Kristensen et al., 1995). There was also evidence that redox oscillations in coastal sediments could enhance OM degradation relative to steady oxic conditions and that OM degradation could go further under oscillating conditions. Aller (1994) incubated pieces of sediments under conditions of oscillating redox and found higher nitrogen storage in the form of $\mathrm{NH}_{4}^{+}$ extractable with $\mathrm{KCl}$, than under steady oxic or steady anoxic conditions. The total number of bacteria was also higher at the end of the incubation under oscillating conditions, which could have been attributed to the fact that redox oscillations induced the death of the bacteria and consequently enhanced their production and the recycling of their biomass. Hulthe et al. (1998) found that buried sediments that had spent a long time under anoxic condition had much faster DIC production rates under oxic conditions than superficial, young oxic sediment. Aller (1998) discussed that the repetitive bacterial biomass recycling due to changes in redox conditions increased the amount of labile OM in the system and promoted the degradation of refractory organic compounds by a "co-oxidation" process. This mechanism, coupled to a permanent availability of poorly crystallised iron oxides available to oxidise $\mathrm{OM}$, explained the efficiency of DMMs in mineralising refractory terrestrial OM at the land-sea interface (Aller, 1998). During our experiment, the short and transient DOC peaks observed during reoxidation periods (Fig. $5 \mathrm{C}$ ) suggested that such processes also occurred in ETMs and that, owing to the redox oscillation, a large amount of highly labile DOC was always available for heterotrophs. Availability of $\mathrm{NO}_{3}^{-}$as an oxidant was also maximised by the redox oscillations and the tight coupling between ammonification, nitrification, denitrification and DRNA (Fig. 3 and Table 4). The result of the $\mathrm{NO}_{3}^{-}$spike confirmed this central role of nitrate-reducing organisms in OM degradation (Fig. 6)

The ability of redox changes to enhance $\mathrm{OM}$ mineralisation rates relative to steady oxic or anoxic conditions strongly depended on the frequency and duration of the oscillations. During our experiment, the duration of the reoxidation period seemed to depend on the former anoxic period, with the ratio between these too durations (reoxidation/preceding anoxia) being relatively constant: 0.55 for the first and shorter period (days 9-10), and 0.30 for the second and longer period (days 22-24). We have modelled the integrated $R_{\mathrm{AM}}$ resulting from different frequencies and durations of redox oscillations, using the rates in Table 4 and assuming reoxidation periods lasted 0.4 times the duration of the previous anoxic period. Table 5 summarises the results of modelled $R_{\mathrm{AM}}$, which were

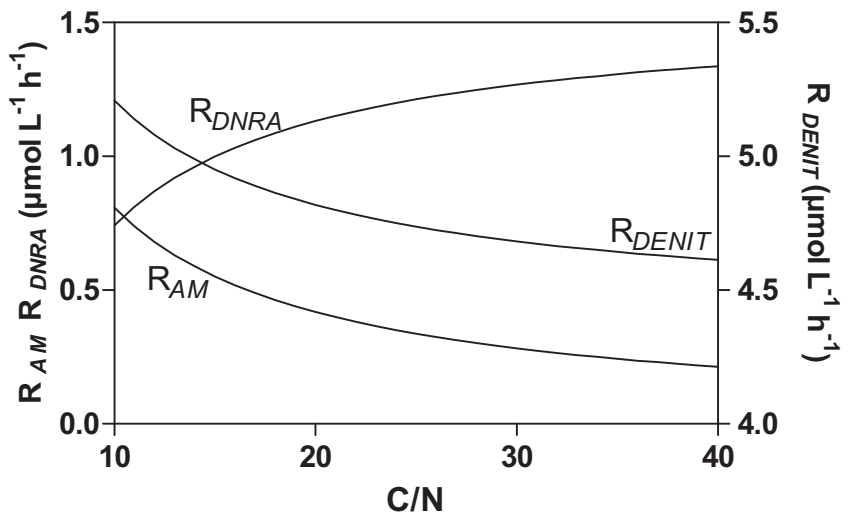

Fig. 7. Impact of the assumed $\mathrm{C} / \mathrm{N}$ ratio for $\mathrm{OM}$ mineralisation on modelled rates of denitrification ( $R_{\mathrm{DENIT}}$, right axis), ammonification $\left(R_{\mathrm{AM}}\right.$, left axis) and dissimilatory reduction of nitrate to ammonium ( $R_{\mathrm{DNRA}}$, left axis). 
Table 5

Nitrogen mineralisation rates under constant and oscillating redox conditions deduced from the rates in Table 3.

\begin{tabular}{|c|c|c|c|c|c|c|c|c|c|}
\hline & $\begin{array}{l}\text { Time oxic } \\
\text { (days) }\end{array}$ & $\begin{array}{l}\text { Time anox } \\
\text { (days) }\end{array}$ & $\begin{array}{l}\text { Time oxic } \\
\text { steady (days) }\end{array}$ & $\begin{array}{l}\text { Time anox } \\
\text { begin (days) }\end{array}$ & $\begin{array}{l}\text { Time anox } \\
\text { steady (days) }\end{array}$ & $\begin{array}{l}\text { Time reox }{ }^{\mathrm{a}} \\
\text { (days) }\end{array}$ & 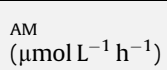 & $\begin{array}{l}\text { Acceleration } \\
\text { relative to oxic (\%) }\end{array}$ & $\begin{array}{l}\text { Acceleration relative } \\
\text { to anoxic (\%) }\end{array}$ \\
\hline Case 1 & $\infty$ & 0 & $\infty$ & 0.0 & 0.0 & 0.0 & 0.70 & 0 & 518 \\
\hline Case 2 & 0 & $\infty$ & 0.0 & 0.0 & $\infty$ & 0.0 & 0.11 & -84 & 0 \\
\hline Case 3 & 1 & 1 & 0.6 & 1.0 & 0 & 0.4 & $0.96-1.12$ & $35-79$ & 744-1006 \\
\hline Case 4 & 6 & 1 & 5.6 & 1.0 & 0.0 & 0.4 & $0.77-0.86$ & $10-23$ & $582-657$ \\
\hline Case 5 & 1 & 6 & 0.0 & 1.0 & 5.0 & 1.0 & $0.57-0.65$ & -7 to 19 & $402-477$ \\
\hline Case 6 & 6 & 6 & 3.6 & 1.0 & 5.0 & 2.4 & $0.91-0.96$ & $31-38$ & $707-751$ \\
\hline
\end{tabular}

a The duration of the reoxidation period was assumed to be 0.4 times the duration of the previous anoxic period.

compared to those under constant oxic and anoxic conditions. As already shown previously (Aller, 1994; Canfield, 1994; Kristensen et al., 1995), $R_{\mathrm{AM}}$ rates were much slower under steady anoxic conditions (Case 2 in Table 4) than under oxic conditions (Case 1) or oscillating conditions (Cases 3-6). Our simple model also revealed that oscillating redox conditions induced a faster OM mineralisation than steady oxic conditions, except when the anoxic periods were too long (Case 5). The estuarine fluid mud in the Gironde estuary underwent redox oscillations at both tidal (1/2 day) and spring-neap (13 days) cycles (Abril et al., 1999). The fastest OM mineralisation occurred when the frequency of oxic/anoxic oscillations was short. For an equivalent duration of the oxic and anoxic periods, $R_{\mathrm{Am}}$ was enhanced by $35-79 \%$ relative to steady oxic conditions when redox conditions changed every day (Case 3 ), whereas the enhancement was only $31-38 \%$ when the switches occurred only every 6 days (Case 6 ). This fact was due to the much lower rates after the first day of anoxia. If anoxic periods became much longer than the oxic period (Case 5), reoxidation conditions prevailed during the whole of the oxic period, but were not necessarily able to compensate for the slowing down that occurred under steady anoxic conditions. On the other hand, a short period of anoxia (less than one day) accelerated the N-mineralisation, regardless of the duration of the oxic period (Case 4). Indeed, because the $R_{\mathrm{AM}}$ of the first day of anoxia was similar to that under oxic conditions, the effect of reoxidation became preponderant and increased the final total $R_{\mathrm{AM}}$.

\section{Conclusion}

Beside limitations due to gas exchange rates and complex inorganic carbon behaviour, the experimental setup presented here was an effective tool to study redox oscillations. We obtained significant new information about the major biochemical processes occurring in the fluid mud of the Gironde estuary. The incubation over 27 days, which included 3 oxic and 2 anoxic periods, confirmed the processes that explain in situ profiles in fluid mud: aerobic respiration, nitrification, ammonification, denitrification, dissimilatory reduction of nitrate to ammonium and manganese oxide reduction by OM. Iron and sulphate reduction, as well as methanogenesis, were minor. The most significant result was the observed enhancement of OM mineralisation during reoxidation periods, unequivocally evidenced by the DIN production rates. This period could not be studied in situ because it took place during the resuspension of the fluid mud, when particles and pore waters were diluted with the upper oxic water. Applying a mass balance model, we calculated that redox oscillations accelerated organic nitrogen mineralisation from $10 \%$ to $79 \%$ according to oscillation frequency.

\section{Acknowledgments}

We thank our colleagues from the LCABIE at the Pau University for first encouraging and then sharing this incubator adventure. Romain Bridou is warmly acknowledged for his drawing of Fig. 1.
This research was supported by the Aquitaine region, the INSU French national institute, and the Adour-Garonne water agency, in the framework of the GIS-ECOBAG research network. M-VC benefited from a PhD grant by the Aquitaine region. We thank one anonymous reviewer and Philip Meysman for their constructive comments.

\section{References}

Abril, G., Frankignoulle, M., 2001. Nitrogen-alkalinity interactions in the highly polluted Scheldt basin (Belgium). Water Research 35, 844-850.

Abril, G., Etcheber, H., Le Hir, P., Bassoullet, P., Boutier, B., Frankignoulle, M., 1999. Oxic/anoxic oscillations and organic carbon mineralization in an estuarine maximum turbidity zone (The Gironde, France). Limnology and Oceanography 44, 1304-1315.

Abril, G., Riou, S.A., Etchber, H., Frankignoulle, M., de Wit, R., Middelburg, J.J., 2000 Transient, tidal time-scale, nitrogen transformation in an estuarine turbidity maximum-fluid mud system (the Gironde, south-west France). Estuarine Coastal and Shelf Science 50, 703-715.

Abril, G., Nogueira, M., Etcheber, H., Cabecadas, G., Lemaire, E., Brogueira, M.J., 2002 Behaviour of organic carbon in nine contrasting European estuaries. Estuarine, Coastal and Shelf Science 54, 241-262.

Abril, G., Etcheber, H., Delille, B., Frankignoulle, M., Borges, A.V., 2003. Carbonate dissolution in the turbid and eutrophic Loire estuary. Marine Ecology, Progress Series 259, 129-138.

Abril, G., Commarieu, M.-V., Maro, D., Fontugne, M., Guérin, F., Etcheber, H., 2004. A massive dissolved inorganic carbon release at spring tide in a highly turbid estuary. Geophysical Research Letters 31, L09316. doi:10.1029/2004GL019714.

Allison, M.A., Lee, M.T., Ogston, A.S., Aller, R.C., 2000. Origin of Amazon mudbanks along the northeastern coast of South America. Marine Geology 163 (1-4), 241-256.

Aller, R.C., 1994. Bioturbation and remobilization of sedimentary organic matter: effects of redox oscillation. Chemical Geology 114, 331-345.

Aller, R.C., 1998. Mobile deltaic and continental shelf muds as suboxic, fluidized bed reactors. Marine Chemistry 61, 143-155.

Aller, R.C., Blair, N.E., 2006. Carbon remineralization in the Amazon-Guianas tropical mobile mudbelt: a sedimentary incinerator. Continental Shelf Research 26, 2241-2259.

Aller, R.C., Heilbrun, C., Panzeca, C., Zhu, Z., Baltzer, F., 2004. Coupling between sedimentary dynamics, early diagenetic processes, and biogeochemical cycling in the Amazon-Guianas mobile mud belt: coastal French Guiana. Marine Geology 208, 331-360.

Andersen, F.O., 1996. Fate of organic carbon added as diatom cells to oxic and anoxic marine sediment microcosms. Marine Ecology, Progress Series 134, 225-233.

Anschutz, P., Sundby, B., Lefrançois, L., Luther, G., Mucci, A., 2000. Interactions between metal oxides and species of nitrogen and iodine in bioturbated marine sediments. Geochimica Cosmochimica Acta 64, 2751-2763.

Anschutz, P., Dedieu, K., Desmazes, F., Chaillou, G., 2005. Solid speciation, oxidation state, and reactivity of manganese in marine sediments. Chemical Geology 281, 265-279.

Anschutz, P., Jorissen, F.J., Chaillou, G., Abu-Zaied, R., Fontanier, C., 2002. Recent turbidite deposition in the eastern Atlantic: early diagenesis and biotic recovery. Journal of Marine Research 60, 835-854.

Blair, N.E., Leithold, E.L., Aller, R.C., 2004. From bedrock to burial: the evolution of particulate organic carbon across coupled watershed-continental margin systems. Marine Chemistry 92, 141-156.

Benson, B.B., Krause, D., 1984. The concentration and isotopic fractionation of oxygen dissolved in freshwater and seawater in equilibrium with the atmosphere. Limnology and Oceanography 29, 620-632.

Borges, A.V., 2005. Do we have enough pieces of the jigsaw to integrate $\mathrm{CO}_{2}$ fluxes in the Coastal Ocean? Estuaries 28 (1), 3-27.

Canfield, D.E., 1994. Factors influencing organic carbon preservation in marine sediments. Chemical Geology 114, 315-329.

Chaillou, G., Anschutz, P., Dubrulle, C., Lecroart, P., 2007. Experimental study of transient diagenesis in modern turbidites. Aquatic Geochemistry 13, 157-172.

Clarens, M., Bernet, N., Delgenès, J.-P., Moletta, R., 1998. Effect of nitrogen oxides and denitrification by Pseudomonas stutzery on acetotrophic methanogenesis by Methanosarcina mazei. FEMS Microbiology Ecology 25, 271-276. 
Dalsgaard, T., Thamdrup, B., 2002. Factors controlling anaerobic ammonium oxidation with nitrite in marine sediments. Applied Environmental Microbiology 68, 3802-3808.

Deflandre, B., Gagné, J.-P., Sundby, B., Mucci, A., Guignard, C., Anschutz, P., 2000. The 1996 flood event: disruption of the ongoing diagenesis of Saguenay Fjord sediments. Proceedings of the Canadian Geotechnical Society 1, 117-122.

Deflandre, B., Mucci, A., Gagne, J.P., Guignard, C., Sundby, B., 2002. Early diagenetic processes in coastal marine sediments disturbed by a catastrophic sedimentation event. Geochimica Cosmochimica Acta 66, 2379-2390.

Etcheber, H., Taillez, A., Abril, G., Garnier, J., Servais, P., Moatar, F., Commarieu, M.-V. 2007. Particulate organic carbon in the estuarine turbidity maxima of the Gironde, Loire and Seine estuaries: origin and lability. Hydrobiologia 588, 245-259.

Frankignoulle, M., Abril, G., Borges, A.V., Bourge, I., Canon, C., Delille, B., Libert, E., Théate, J.M., 1998. Carbon dioxide emission from European estuaries. Science 282, 434-436.

Gattuso, J.-P., Frankignoulle, M., Wollast, R., 1998. Carbon and carbonate metabolism in coastal aquatic ecosystems. Annual Review of Ecology and Systematic 29, 405-434.

Gilbert, F., Souchu, P., Bianchi, M., Bonin, P., 1998. Influence of shell fish farming activities on nitrification, nitrate reduction to ammonium and denitrification at the sediment water interface of the Thau lagoon, France. Marine Ecology Progress Series 151, 143-153.

Hulth, S., Aller, R., Gilbert, F., 1999. Coupled anoxic nitrification/manganese reduction in marine sediments. Geochimica Cosmochimica Acta 63, 49-66.

Hulthe, G., Hulth, S., Hall, P.O., 1998. Effect of oxygen on degradation rate of refractory and labile organic matter on continental margin sediments. Geochimica Cosmochimica Acta 62, 1319-1328.

Jouanneau, J.-M., Weber, O., Cremer, M., Castaing, P., 1999. Fine-grained sediment budget on the continental margin of the Bay of Biscay. Deep Sea Research Part II. 46, 2205-2220.

Jouanneau, J.-M., Weber, O., Champilou, N., Cirac, P., Muxika, I., Borja, A., Pascual, A. Rodríguez-Lázaro, J., Donard, O., 2008. Recent sedimentary study of the shelf of the Basque country. Journal of Marine Systems 72, 397-406.

Jørgensen, B.B., 1982. Mineralization of organic matter in the sea bed - the role of sulphate reduction. Nature 296, 643-645.

Kelly-Gerreyn, B.A., Trimmer, M., Hydes, DJ., 2001. A diagenetic model discriminating denitrification and dissimilatory nitrate reduction to ammonium in temperate estuarine sediment. Marine Ecology Progress Series 220, 33-46.

Keil, R.G., Mayer, L.M., Quay, P.D., Richey, J.E., Hedges, J.I., 1996. Loss of organic matter from riverine particles in deltas. Geochimica Cosmochimica Acta 61, 1507-1511.

Kristensen, E., Ahmed, S.I., Devol, A.H., 1995. Aerobic and anaerobic decomposition of organic matter in marine sediment: which is fastest? Limnology and Oceanography 40, 1430-1437.

Luther, G., Sundy, B., Lewis, B., Brendel, P., Silverburg, N., 1997. Interactions of manganese with the nitrogen cycle: alternative pathways to dinitrogen. Geochimica Cosmochimica Acta 61, 4043-4052.

Mehrbach, C., Culberson, C., Hawley, J.E., Pytkowich, R.M., 1973. Measurements of the apparent dissociation constants of carbonic acid in seawater at atmospheric pressure. Limnology and Oceanography 18, 897-907.
Middelburg, J.J., De Lange, G.J., van der Weijden, C.H., 1987. Manganese solubility control in marine pore waters. Geochimica Cosmochimica Acta 51, 759-763.

Middelburg, J.J., Nieuwenhuize, J., 2000. Dissolved inorganic nitrogen uptake in turbid, tidal estuaries. Marine Ecology Progress Series 192, 79-88.

Middelburg, J.J., Herman, P.M.J., 2007. Organic matter processing in tidal estuaries. Marine Chemistry 106, 127-147.

Mortimer, R.J.G., Harris, S.J., Krom, M.D., Freitag, T., Prosser, J.I., Barnes, J., Anschutz, P., Hayes, P., Davies, I.M., 2004. Anoxic nitrification in marine sediments. Marine Ecology Progress Series 276, 37-51.

Mucci, A., 1988. Manganese uptake during calcite precipitation from seawater: conditions leading to the formation of a pseudokutnahorite. Geochimica Cosmochimica Acta 52, 1859-1868.

Oremland, R.S., Polcin, S., 1982. Methanogenesis and sulfate reduction: competitive and non-competitive substrates in estuarine sediments. Applied and Environmental Microbiology 44, 1270-1276.

Raghoebarsing, A.A., Pol, A., van de Pas-Schoonen, K.T., Smolders, A.J.P., Ettwig, K.F., Rijpstra, W.I.C., Schouten, S., Damsté, J.S.S., Op den Camp, H.J.M., Jetten, M.S.M., Strous, M., 2006. A microbial consortium couples anaerobic methane oxidation to denitrification. Nature 440, 918-921.

Rysgaard, S., Glud, R.N., Risgaard-Petersen, N., Dalsgaard, T., 2004. Denitrification and anammox activity in Arctic marine sediments. Limnology and Oceanography $45,1493-1502$.

Rodier, J., 1976. L'analyse de l'eau, eaux naturelles, eaux résiduaires, eau de mer. In: Dunod (Ed.), Paris, 364 pp.

Roy, R., Conrad, R., 1999. Effect of methanogenic precursors (acetate, hydrogen, propionate) on the suppression of methane production by nitrate in anoxic rice field soil. FEMS Microbiology Ecology 28, 49-61.

Stookey, L.L., 1970. Ferrozine-A new spectrophotometric reagent for iron. Analytica Chimica Acta 42, 779-781.

Stumm, W., Morgan, J.J., 1996. Aquatic Chemistry: Chemical Equilibria and Rates in Natural Waters, third ed. p. 474

Sun, M., Lee, C., Aller, R.C., 1993. Laboratory studies and anoxic degradation of chlorophyll- $a$ in Long Island Sound sediments. Geochimica Cosmochimica Acta 57, 147-157.

Sun, M., Aller, R.C., Lee, C., Wakeham, S.T., 2002. Effects of oxygen and redox oscillation on degradation of cell-associated lipids in surficial marine sediments. Geochimica Cosmochimica Acta 66, 2003-2012.

Trimmer, M., Nicholls, J.C., Deflandre, B., 2003. Anaerobic ammonium oxidation measured in sediments along the Thames Estuary, UK. Applied Environmental Microbiology 69, 6447-6454.

Wagman, D.D., Evans, W.H., Parker, V.B., Schumm, R.H., Harlow, I., Bailey, S.M., Churney, K.L., Nutall, R.L., 1982. The NBS tables of chemical thermodynamic properties: selected values for inorganic and $C_{1}$ and $C_{2}$ organic substances in SI units. Journal of Physical and Chemical Reference Data 11 (Suppl No. 2).

Weiss, R.F., 1974. Carbon dioxide in water and seawater: the solubility of a non-ideal gas. Marine Chemistry 2, 203-215.

Yamamoto, S., Alcauskas, J.B., Crozier, T.E., 1976. Solubility of methane in distilled water and seawater. Journal of Chemical Engineering and Data 21, $78-80$. 